\title{
Passerine Exposure to Primarily PCDFs and PCDDs in the River Floodplains Near Midland, Michigan, USA
}

\author{
Timothy B. Fredricks • Matthew J. Zwiernik • Rita M. Seston • \\ Sarah J. Coefield - Stephanie C. Plautz • Dustin L. Tazelaar • \\ Melissa S. Shotwell • Patrick W. Bradley • Denise P. Kay • \\ John P. Giesy
}

Received: 7 April 2009/Accepted: 13 October 2009/Published online: 6 November 2009

(C) The Author(s) 2009. This article is published with open access at Springerlink.com

\begin{abstract}
House wren (Troglodytes aedon), tree swallow (Tachycineta bicolor), and eastern bluebird (Sialia sialis) tissues collected in study areas (SAs) downstream of Midland, Michigan (USA) contained concentrations of polychlorinated dibenzofurans (PCDFs) and polychlorinated dibenzo-p-dioxins (PCDDs) greater than in upstream reference areas (RAs) in the region. The sum of concentrations of $\mathrm{PCDD} / \mathrm{DFs}$ ( $\Sigma \mathrm{PCDD} / \mathrm{DFs}$ ) in eggs of house wrens and eastern bluebirds from SAs were 4- to 22-fold greater compared to those from RAs, whereas concentrations in tree swallow eggs were similar among areas. Mean concentrations of $\Sigma \mathrm{PCDD} / \mathrm{DFs}$ and sum 2,3,7,8-tetrachlorodibenzo- $p$-dioxin equivalents $\left(\Sigma \mathrm{TEQs}_{\mathrm{WHO}-\mathrm{Avian}}\right)$, based
\end{abstract}

Electronic supplementary material The online version of this article (doi:10.1007/s00244-009-9416-6) contains supplementary material, which is available to authorized users.

T. B. Fredricks $(\bowtie) \cdot$ R. M. Seston · S. J. Coefield · J. P. Giesy Department of Zoology, Michigan State University,

East Lansing, MI 48824, USA

e-mail: fredri29@msu.edu

T. B. Fredricks

Ecotoxicology Section, Bayer CropScience, 17745 South

Metcalf, Stilwell, KS 66085, USA

\section{J. Zwiernik · D. L. Tazelaar · P. W. Bradley}

Department of Animal Science, Michigan State University,

East Lansing, MI 48824, USA

S. C. Plautz

Cooperative Wildlife Research Laboratory, Southern Illinois

University, Carbondale, IL 62901, USA

M. S. Shotwell · D. P. Kay

ENTRIX, Inc., Okemos, MI 48864, USA on 1998 WHO avian toxic equivalency factors, in house wren and eastern bluebird eggs ranged from 860 (430) to $1500(910) \mathrm{ng} / \mathrm{kg}$ wet weight (ww) and $470(150)$ to 1100 (510) $\mathrm{ng} / \mathrm{kg} \mathrm{ww}$, respectively, at the most contaminated study areas along the Tittabawassee River, whereas mean concentrations in tree swallow eggs ranged from 280 (100) to 760 (280) ng/kg ww among all locations. Concentrations of $\Sigma$ PCDD/DFs in nestlings of all studied species at SAs were 3- to 50-fold greater compared to RAs. Mean house wren, tree swallow, and eastern bluebird nestling concentrations of $\Sigma \mathrm{PCDD} / \mathrm{DFs}$ and $\Sigma$ TEQs $\mathrm{WHO}_{\mathrm{W} \text {-Avian }}$ ranged from 350 (140) to 610 (300) ng/kg ww, 360 (240) to 1100 (860) $\mathrm{ng} / \mathrm{kg}$ ww, and 330 (100) to 1200 (690) $\mathrm{ng} / \mathrm{kg}$ ww, respectively, at SAs along the Tittabawassee River. Concentrations of $\Sigma T E Q s_{W H O-A v i a n}$ were positively correlated with $\Sigma \mathrm{PCDD} / \mathrm{DF}$ concentrations in both eggs and nestlings of all species studied. Profiles of relative concentrations of

\author{
J. P. Giesy \\ Department of Veterinary Biomedical Sciences and Toxicology \\ Centre, University of Saskatchewan, Saskatoon, Saskatchewan \\ S7J 5B3, Canada \\ J. P. Giesy \\ Department of Biology and Chemistry, City University of Hong \\ Kong, Kowloon, Hong Kong SAR, China \\ J. P. Giesy \\ College of Environment, Nanjing University of Technology, \\ Nanjing 210093, China \\ J. P. Giesy \\ Key Laboratory of Marine Environmental Science, College of \\ Oceanography and Environmental Science, Xiamen University, \\ Xiamen, People's Republic of China
}


individual congeners were dominated by furan congeners (69-84\%), primarily 2,3,7,8-tetrachlorodibenzofuran and 2,3,4,7,8-pentachlorodibenzofuran, for all species at SAs on the Tittabawassee and Saginaw rivers but were dominated by dioxin congeners at upstream RAs.

Concentrations of polychlorinated dibenzofurans (PCDFs) and polychlorinated dibenzo- $p$-dioxins (PCDDs) in soil and sediment in portions of the Tittabawassee and Saginaw rivers and associated floodplain downstream of Midland, Michigan (USA) are greater than the background concentration for the region (Hilscherova et al. 2003). Potential sources of the PCDD/DFs are historical production of organic chemicals and on-site storage and disposal, prior to the establishment of modern waste management protocols (Amendola and Barna 1986). The congener profile of the PCDD/DFs is dominated by 2,3,4,7,8-pentachlorodibenzofuran (PeCDF), which is consistent with the waste stream of a chloralkali plant using a graphite-electrode process (Rappe et al. 1991; Svensson et al. 1993). The lipophilic nature and slow degradation rates of these compounds (Mandal 2005), combined with consistent inundation of the floodplain, led to the continued presence of PCDD/DFs in floodplain soils and sediments.

PCDD/DFs occur in the environment as mixtures and have potential to be accumulated through the food web. Greater than background concentrations of dioxinlike compounds have been previously measured in upper trophic level organisms downstream of Midland, Michigan. The Michigan Department of Public Health first issued fish consumption advisories in 1978 based on elevated concentrations of PCDFs, PCDDs, and polychlorinated biphenyls (PCBs) in tissues of fish collected downstream of Midland. Wild game consumption advisories were issued in 2004 based on elevated concentrations in deer and turkey.

One set of toxicological responses to dioxinlike compounds is mediated through the aryl hydrocarbon receptor (AhR). These AhR-mediated responses include carcinogenicity, immunotoxicity, and adverse effects on reproduction, development, and endocrine functions (van den Berg et al. 1998). In particular, AhR-mediated compounds have been shown to decrease hatching success, adult responsiveness, and immune function and to increase CYP1A enzyme induction of birds (Hoffman et al. 1998; Nosek et al. 1992a, 1993; Powell et al. 1996, 1998; Thiel et al. 1988). Recent findings provide evidence of the molecular basis for variation in avian species sensitivity to dioxinlike compounds (Head et al. 2008; Karchner et al. 2006).

Three cavity-nesting passerine birds were selected for study to provide data for a site-specific ecological risk assessment of the Tittabawassee and Saginaw rivers and associated floodplain downstream of Midland, Michigan using the multiple-lines-of-evidence approach described by Fairbrother (2003). Prior to the initiation of research, species were selected based on their applicability and the predicted statistical power of data collected to test hypotheses associated with ecosystem health. Applicability was determined based on similarities in nesting characteristics, resistance to disturbance, foraging range and expected species density based on habitat availability, and use as a receptor in previous contamination research. These similarities allow for a more direct comparison of the parameters of interest, including differences in stressor exposure based on divergent foraging characteristics as well as differences in species stressor sensitivity.

Based on the above criteria, the tree swallow (Tachycineta bicolor), house wren (Troglodytes aedon), and eastern bluebird (Sialia sialis) were selected as study species for this research. All are obligate cavity-nesters with limited foraging range and similar site fidelity. Tree swallows are aquatic insectivores (Kuerzi 1941), primarily feeding on emergent insects (McCarty 1997; McCarty and Winkler 1999; Mengelkoch et al. 2004), and have been extensively utilized in contaminant studies (Custer et al. 2005; Echols et al. 2004; Froese et al. 1998; Neigh et al. 2006b; Shaw 1983). Eastern bluebirds and house wrens are both terrestrial insectivores (Beal 1915; Guinan and Sealy 1987) but have different habitat preferences and foraging strategies that could lead to different contaminant accumulation. Eastern bluebirds prefer open grassland habitats and feed by dropping on prey from an elevated perch, whereas house wrens primarily glean insects off foliage in brushy/forested habitats. Several studies of contaminants have used eastern bluebirds and house wrens (Burgess et al. 1999; Custer et al. 2001; Henny et al. 1977; Mayne et al. 2004; Neigh et al. 2006a, 2007).

The primary goal of the study was to characterize PCDD/DF exposure for these three passerine species representing different feeding pathways. To that end, eggs and nestlings of each species were examined for the following: (1) concentrations of $\Sigma \mathrm{PCDD} / \mathrm{DF}$ and 2,3,7,8-tetrachlorodibenzo- $p$-dioxin (TCDD) equivalents (TEQ ${ }_{\mathrm{WHO}-\mathrm{Avian}}$ ) based on World Health Organization (WHO) 2,3,7,8TCDD equivalency factors for birds $\left(\mathrm{TEF}_{\mathrm{WHO}}\right.$-Avian $)$ (van den Berg et al. 1998); (2) temporal, spatial, and speciesspecific trends in concentrations; and (3) patterns of relative concentrations of individual congeners. Eggs were studied to account for maternal transfer of contaminants to the developing embryo, whereas concentrations of PCDD/ $\mathrm{DF}$ in nestlings were considered to be more representative of site-specific exposures. Comparisons of congener-specific concentrations stratified by feeding pathway and site 
provided information about the sources of contaminants and species-specific exposure pathways.

The portion of the research described here focused on tissue-based exposure analyses. Results for the dietarybased exposure (Fredricks et al. 2009a) and nest productivity (Fredricks et al. 2009c) are reported elsewhere. Incorporation of all three lines of evidence into an ecological risk assessment will eventually lead to informed decisions about the potential impact(s) of on-site exposure and will aid in both the planning and evaluation of effective remedial actions.

\section{Methods}

\section{Site Description}

The research was conducted on the Tittabawassee, Chippewa, and Saginaw rivers, in the vicinity of Midland, Michigan (Fig. 1). The reference areas (RAs) were located upstream of the putative sources of $\mathrm{PCDD} / \mathrm{DF}$ (Hilscherova et al. 2003) on the Tittabawassee (R-1) and Chippewa (R-2) rivers (Fig. 1). The area downstream of the putative PCDD/DF sources, defined as the study area (SA), includes $\sim 72 \mathrm{~km}$ of the Tittabawassee and Saginaw rivers. The SA stretched from the upstream boundary, defined as the lowhead dam near Midland, Michigan, to where the Saginaw River enters Saginaw Bay. Throughout the SA, the
Tittabawassee River is free-flowing to the confluence with the Saginaw River and eventually Saginaw Bay. The SA consisted of two areas: the Tittabawassee River study areas, which included four locations (T-3 to T-6), and the Saginaw River study areas, which included two locations (S-7 and S-9). S-7 is located on a peninsula between the Tittabawassee and Saginaw rivers just upstream of their confluence. The six SAs were selected based on availability of landowner access to the sites and expected high-end exposure based on a previous study that measured soil and sediment concentrations (Hilscherova et al. 2003).

Nest Boxes

Nest boxes were used to facilitate monitoring of nesting activity and collection of samples. Standard passerine nest boxes (cedar; $\sim 12 \mathrm{~cm} \times 12 \mathrm{~cm} \times 20 \mathrm{~cm}$ with a $3.5-\mathrm{cm}$ hole) were fitted with a wire mesh predator guard around the entrance, mounted on 2.13-m metal T-posts covered in lubricating grease (to deter predator access), and placed at individual study locations R-1 to T-6 in 2004. Two additional sites (S-7 and S-9) were added in 2005. Nest boxes were placed in appropriate habitats to accommodate and target all three species (Horn et al. 1996; Parren 1991) and, when possible, to prevent competition among species (Prescott 1982). Nests were monitored from mid-April through the end of the breeding season beginning in 2005 and for the following 2 years (2006 and 2007). Procedures
Fig. 1 Study site locations within the Chippewa River, Tittabawassee River, and Saginaw River floodplains, Michigan (USA) Reference areas (R-1 to R-2),

Tittabawassee River study areas (T-3 to T-6), and Saginaw River study areas (S-7 and S-9) were monitored from 2005 to 2007. The direction of river flow is designated by arrows; suspected source of contamination is enclosed in the dashed oval

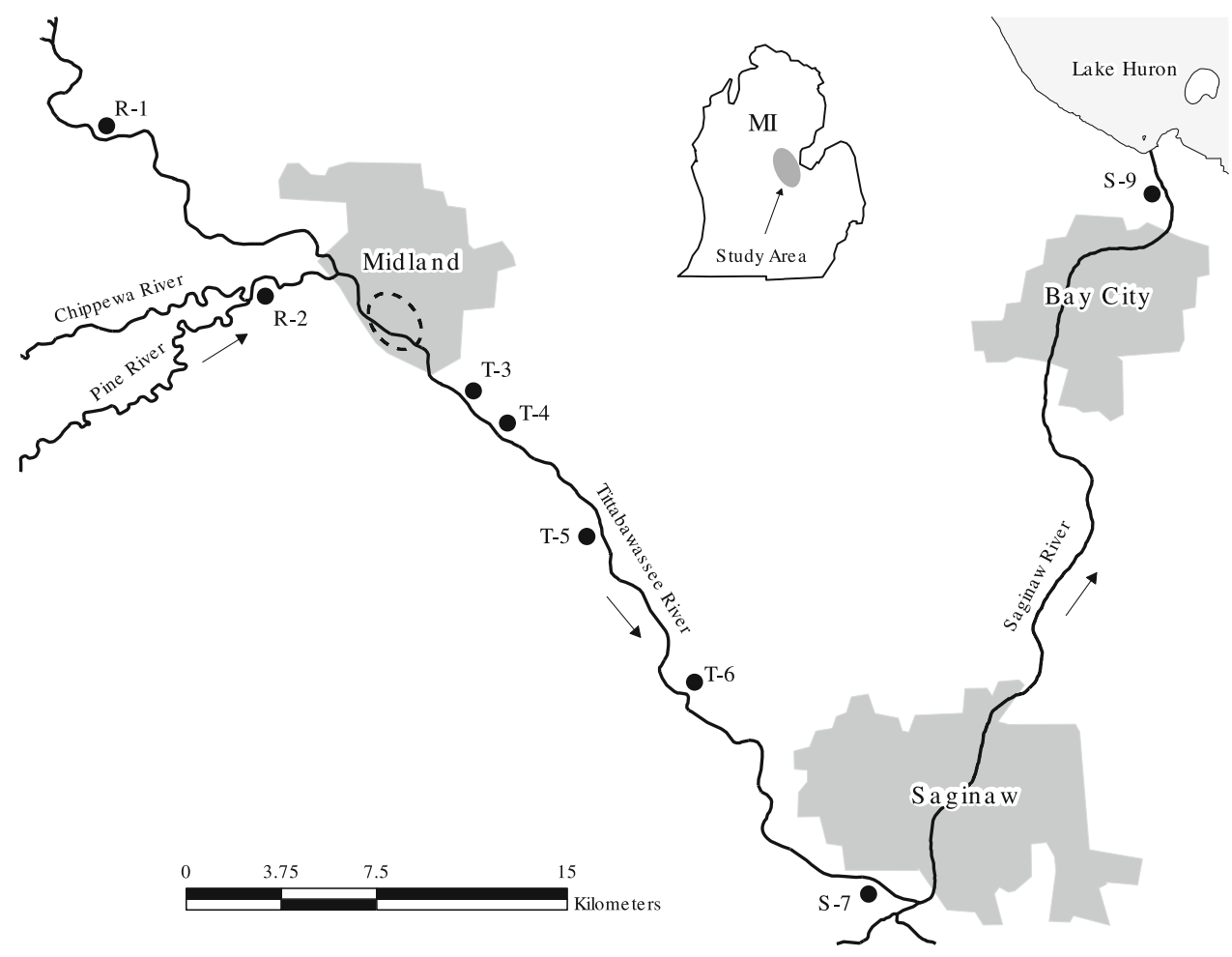


generally followed those used by McCarty and Secord (1999).

\section{Tissue Collection}

Both eggs and nestlings were collected for quantification of PCDD/DFs. Nest boxes were randomly selected from the active nest boxes at a given location for either live egg or nestling collections but not both. Fresh egg mass was determined on the date laid. Abandoned and addled eggs were collected for possible quantification of PCDD/DF congeners and determination of degree of development after no activity for 7 days (3-4 days posthatch for addled eggs) or by the presence of new nesting material. Addled eggs were defined as those that failed to hatch 3-4 days posthatch of the remainder of the clutch. Eggs were individually stored wrapped in chemically cleaned foil in a chemically clean glass jar (I-CHEM, Rockwood, TN) at ambient temperature in the field and refrigerated at $4^{\circ} \mathrm{C}$. In the laboratory, collected eggs were opened around the girth with a chemically cleaned scalpel blade and assessed for stage of development and the presence of any abnormalities (Giesy et al. 1994; Larson et al. 1996). Nestlings (one per box) were collected at 10 days posthatch for house wrens or 14 days posthatch for eastern bluebirds and tree swallows and then euthanized via cervical dislocation. Nestlings were stored in similar glass jars on wet ice in the field and at $-20^{\circ} \mathrm{C}$ until analyses. In the laboratory, collected nestlings were homogenized without feathers, bill, legs, and gizzard and crop contents with a chemically cleaned stainless-steel Omni-mixer ${ }^{\circledR}$ (Omni International, Marietta, GA). The homogenates were stored at $-20^{\circ} \mathrm{C}$ until extraction.

During the 2005-2007 breeding seasons, a total of 49, 50 , and 35 live and addled eggs were collected from unique house wren, tree swallow, and eastern bluebird clutches, respectively. An additional 9 eggs from 4 house wren clutches, 10 eggs from 4 tree swallow clutches, and 13 eggs from 5 eastern bluebird clutches were collected for withinclutch variability monitoring. During the same sampling period, 48, 45, and 30 nestlings were collected from unique house wren, tree swallow, and eastern bluebird clutches, respectively. However, of the collected nestlings, 10, 17, and 10 nestlings were collected from clutches in which an addled egg was also analyzed for house wrens, tree swallows, and eastern bluebirds, respectively.

\section{Identification and Quantification of PCDD/DF Congeners}

Concentrations of seventeen 2,3,7,8-substituted PCDD/DF congeners were measured in all samples, whereas concentrations of 12 non- and mono-ortho-substituted PCBs and dichloro-diphenyl-trichloroethane and related metabolites (DDXs) were determined in a subset of these samples. Eggs were lyophilized and stored at $-20^{\circ} \mathrm{C}$ until extraction. Egg content mass was calculated by subtracting the egg shell mass at dissection from the total fresh egg mass measured on the day laid. Masses were calculated for quantification purposes and to account for any desiccation of the eggs during incubation and storage. Because actual fresh egg masses were determined on the date laid, it was not necessary to adjust for moisture loss, as has been suggested by previous research (Adrian and Stevens 1979; Heinz et al. 2009; Peakall and Gilman 1979; Stickel et al. 1973).

The PCDD/DFs, PCBs, and DDXs were quantified in accordance with EPA Method 8290/1668A with minor modifications (USEPA 1998). Briefly, samples were homogenized with anhydrous sodium sulfate and Soxhlet extracted in hexane:dichloromethane (1:1) for $18 \mathrm{~h}$. Before extraction, known amounts of ${ }^{13} \mathrm{C}$-labeled analytes were added to the sample as internal standards. The extraction solvent was exchanged to hexane and the extract was concentrated to $10 \mathrm{~mL}$. Ten percent of this extract was removed for lipid content determination. Extracts were initially purified by treatment with concentrated sulfuric acid. The extract was then passed through a silica gel column containing silica gel and sulfuric acid silica gel and eluted with hexane. The extract was then separated into two fractions by elution through acidic alumina: Fraction one contained most PCBs and pesticide compounds and fraction two contained PCDD/DFs and coplanar PCBs. Fraction two of the alumina column was then passed through a carbon column packed with $1 \mathrm{~g}$ of activated carbon-impregnated silica gel. The first carbon fraction, eluted with various solvent mixtures, was combined with the fraction one eluate from the acidic alumina column and retained for PCBs and DDXs analyses. The PCBs and DDXs extract was split, and separate analyses were performed using high resolution gas chromatography/high resolution mass spectroscopy (HRGC/HRMS) under the guidance of EPA method 1668, revision A. The second fraction, eluted with toluene, contained the PCDD/DFs and PCBs (IUPAC Nos. 77, 81, 126, and 169). Components were analyzed using HRGC/HRMS, a Hewlett-Packard 6890 GC (Agilent Technologies, Wilmington, DE) connected to a MicroMass ${ }^{\circledR}$ high-resolution mass spectrometer (Waters Corporation, Milford, MA). PCDF, PCDD, PCB, and DDX congeners were separated on a DB-5 capillary column (Agilent Technologies, Wilmington, DE) coated at $0.25 \mu \mathrm{m}(60 \mathrm{~m} \times 0.25 \mathrm{~mm}$ inner diameter $)$. The mass spectrometer was operated at an electron-impact ionization (EI) energy of $60 \mathrm{eV}$ and an ion current of $600 \mu \mathrm{A}$. Congeners were identified and quantified by use of singleion monitoring (SIM) at the two most intensive ions at the molecular ion cluster. Concentrations of certain PCDD/DF 
congeners, particularly 2,3,7,8-TCDD and 2,3,7,8-tetrachlorodibenzofuran (TCDF) congeners, were confirmed by using a DB-225 $(60 \mathrm{~m} \times 0.25 \mathrm{~mm}$ inner diameter, $0.25 \mu \mathrm{m}$ film thickness) column (Agilent Technologies, Wilmington, DE). Losses of congeners during extraction and cleanup were corrected based on recoveries of ${ }^{13} \mathrm{C}$-labeled analytes as outlined in EPA Method 8290/ 1668A. Quality control samples generated during chemical analyses included laboratory method blanks, sample processing blanks (equipment rinsate and atmospheric), matrix spike and matrix spike duplicate pairs, unspiked sample replicates, and blind check samples. Results of method and field blank analyses indicated no systematic laboratory contamination issues. Evaluation of the percent recovery and relative percent difference data for the matrix spike and matrix spike duplicate samples and unspiked replicate samples were within $\pm 30 \%$ at a rate of greater than $95 \%$ acceptability.

\section{Statistical Analyses}

Total concentrations of the 17 2,3,7,8-substituted PCDD/ DF congeners are reported as the sum of all congeners $[\mathrm{ng} / \mathrm{kg}$ wet weight $(\mathrm{ww})]$. Individual congeners that were less than the limit of quantification were assigned a value of half the sample method detection limit. Total concentrations of 12 non- and mono-ortho-substituted PCB congeners are reported as the sum of these congeners ( $\Sigma$ PCBs; ng $/ \mathrm{kg}$ ww). Concentrations of TEQ ${ }_{\text {WHO-Avian }}$ (ng/kg ww) were calculated for both PCDD/DFs and PCBs by summing the product of the concentration of each congener, multiplied by its avian $\mathrm{TEF}_{\mathrm{WHO}-\mathrm{Avian}}$ (van den Berg et al. 1998). Additionally, dichloro-diphenyl-trichloroethane $\left(2^{\prime}, 4^{\prime}\right.$ and $4^{\prime}, 4^{\prime}$ isomers $)$ and dichloro-diphenyl-dichloroethylene $\left(4^{\prime}, 4^{\prime}\right)$ are reported as the sum of the $o, p$ and $p, p$ isomers ( $\Sigma$ DDXs; $\mu \mathrm{g} / \mathrm{kg} \mathrm{ww}$ ) for the same subset of samples as for PCBs. Geometric means and $95 \%$ confidence intervals are presented.

Sample sizes reported for both eggs and nestlings were collected from individual nest boxes from unique nesting attempts. However, some clutches had analytical data reported for both an addled egg and nestling, which is similar to previous research (Custer et al. 2003, 2005). Multiple eggs sampled from the same nesting attempt only were used for investigating clutch variability trends, with the exception that a single egg was randomly selected and included in the between-site comparisons. Comparisons of site-specific differences between live and addled eggs were made using the same egg dataset as for among sites comparisons. Correlations between concentrations of $\Sigma \mathrm{PCDD} /$ DFs and TEQ ${ }_{\text {WHO-Avian }}$ in eggs and lay order, clutch initiation dates, and date collected were made by species and only included the eggs used for between-site comparisons.
No statistical comparisons were made for analytical results for cocontaminants or among multiple eggs sampled from the same nesting attempt for clutch variability trends.

Statistical analyses were performed using SAS $^{\circledR}$ software (Release 9.1; SAS Institute Inc., Cary, NC, USA). Prior to the use of parametric statistical procedures, normality was evaluated using the Shapiro-Wilks test and the assumption of homogeneity of variance was evaluated using Levene's test. Values that were not normally distributed were transformed using the natural $\log (\ln )$ of $(x+1)$. Concentrations in eggs and nestlings were initially tested for overall effects, including the following class variables: YEAR, SPECIES, SAMPLE, and SITE without interaction terms for concentrations of both $\Sigma \mathrm{PCDD} / \mathrm{DFs}$ and TEQ ${ }_{W H O-A v i a n}$. Subsequent one-way comparisons were made for all YEARs combined and separated by SPECIES and SAMPLE testing for differences in concentrations of $\Sigma$ PCDD/DFs and TEQ sample size limitations, one-way comparisons between live and addled eggs were made by species for only sites R-1 and R-2, T-3 to T-6, and S-7 and S-9. PROC GLM was used to make comparisons for three or more groups. When significant differences among locations were indicated, Bonferroni's $t$-test was used to compare individual locations. PROC TTEST was used to compare between only two groups. The associations between concentrations of both $\Sigma$ PCDD/DFs and TEQ ${ }_{\text {WHO-Avian }}$ and order in which eggs were laid (relative position of egg within laying sequence) and date egg laid (Julian date) were evaluated individually by Pearson's correlation coefficients. No statistical comparisons were made between multiple eggs collected from the same clutch (within-clutch variability) or for samples screened for potential cocontaminants (PCBs and DDXs). Differences were considered to be statistically significant at $p<0.05$.

\section{Results}

\section{$\Sigma \mathrm{PCDD} / \mathrm{DF}, \Sigma \mathrm{PCB}$, and $\Sigma \mathrm{DDX}$ Concentrations}

Concentrations of $\Sigma \mathrm{PCDD} / \mathrm{DF}$ in neither eggs nor nestlings were different among years, but concentrations of $\Sigma$ PCDD/DFs did vary between eggs and nestlings as well as among species and locations. Because there was no difference in concentrations of $\Sigma \mathrm{PCDD} / \mathrm{DFs}$ among years $(F=2.46, p=0.0877)$, comparisons were made by species $(F=9.53, p=0.0001)$ and sample type $(F=54.19$, $p<0.0001)$ when comparing among sampling locations $(F=44.52, p<0.0001)$.

Concentrations of $\Sigma \mathrm{PCDD} / \mathrm{DF}$ in eggs of both house wrens and eastern bluebirds were significantly different among sampling locations, whereas concentrations of 
Table 1 Total concentrations of furans and dioxins $(\Sigma \mathrm{PCDD} / \mathrm{DF})$ and TEQs $\mathrm{WHO}_{\mathrm{W} \text {-Aian }}$ in eggs ${ }^{\mathrm{a}}$ of house wrens, tree swallows and eastern bluebirds collected during 2005-2007 from the Chippewa River, Tittabawassee River, and Saginaw River floodplains, Midland, Michigan, USA

\begin{tabular}{|c|c|c|c|c|c|c|c|c|}
\hline & \multicolumn{2}{|c|}{ Reference area } & \multicolumn{6}{|l|}{ Study area } \\
\hline & $\mathrm{R}-1$ & $\mathrm{R}-2$ & $\mathrm{~T}-3$ & $\mathrm{~T}-4$ & T-5 & T-6 & S-7 & S-9 \\
\hline \multicolumn{9}{|l|}{ House wren } \\
\hline$\Sigma \mathrm{PCDD} / \mathrm{DF}$ & $\begin{array}{l}73(6) \mathrm{A}^{\mathrm{b}} \\
(28-190)\end{array}$ & $\begin{array}{l}82(6) \mathrm{A} \\
(53-130)\end{array}$ & $\begin{array}{l}1400(9) \mathrm{C} \\
(810-2500)\end{array}$ & $\begin{array}{l}990(7) \mathrm{C} \\
(390-2500)\end{array}$ & $\begin{array}{l}860(6) \mathrm{BC} \\
(510-1400)\end{array}$ & $\begin{array}{l}1500(6) \mathrm{C} \\
(860-2600)\end{array}$ & $\begin{array}{l}480(6) \mathrm{BC} \\
(220-1000)\end{array}$ & $\begin{array}{l}200(3) \mathrm{AB} \\
(33-1200)\end{array}$ \\
\hline TEQ & $\begin{array}{l}10(6) \mathrm{A} \\
(4.8-21)\end{array}$ & $\begin{array}{l}25(6) \mathrm{AB} \\
(14-44)\end{array}$ & $\begin{array}{l}860 \text { (9) D } \\
(420-1700)\end{array}$ & $\begin{array}{l}360(7) \mathrm{D} \\
(190-650)\end{array}$ & $\begin{array}{l}430(6) \mathrm{D} \\
(220-820)\end{array}$ & $\begin{array}{l}910(6) \mathrm{D} \\
(460-1800)\end{array}$ & $\begin{array}{l}240(6) \mathrm{CD} \\
(100-580)\end{array}$ & $\begin{array}{l}79 \text { (3) BC } \\
(12-470)\end{array}$ \\
\hline \multicolumn{9}{|l|}{ Tree swallow } \\
\hline$\Sigma \mathrm{PCDD} / \mathrm{DF}$ & $\begin{array}{l}660 \text { (7) A } \\
(340-1300)\end{array}$ & $\begin{array}{l}760 \text { (7) A } \\
(440-1300)\end{array}$ & $\begin{array}{l}470(8) \mathrm{A} \\
(300-740)\end{array}$ & $\begin{array}{l}540(6) \mathrm{A} \\
(350-850)\end{array}$ & $\begin{array}{l}(2)^{\mathrm{d}} \\
(460-490)\end{array}$ & $\begin{array}{l}380(7) \mathrm{A} \\
(170-850)\end{array}$ & $\begin{array}{l}400(7) \mathrm{A} \\
(280-570)\end{array}$ & $\begin{array}{l}280(6) \mathrm{A} \\
(220-360)\end{array}$ \\
\hline TEQ & $\begin{array}{l}180(7) \mathrm{A} \\
(73-420)\end{array}$ & $\begin{array}{l}280(7) \mathrm{A} \\
(180-430)\end{array}$ & $\begin{array}{l}220(8) \mathrm{A} \\
(140-360)\end{array}$ & $\begin{array}{l}240(6) \mathrm{A} \\
(130-460)\end{array}$ & $\begin{array}{l}(2) \\
(190-330)\end{array}$ & $\begin{array}{l}220(7) \mathrm{A} \\
(73-700)\end{array}$ & $\begin{array}{l}190(7) \mathrm{A} \\
(120-300)\end{array}$ & $\begin{array}{l}100(6) \mathrm{A} \\
(78-140)\end{array}$ \\
\hline \multicolumn{9}{|l|}{ Eastern bluebird } \\
\hline$\Sigma \mathrm{PCDD} / \mathrm{DF}$ & $\begin{array}{l}51(6) \text { A } \\
(20-130)\end{array}$ & $\begin{array}{l}130(6) \mathrm{AB} \\
(84-220)\end{array}$ & $\begin{array}{l}470 \text { (6) BC } \\
(200-1100)\end{array}$ & $\begin{array}{l}620(6) \mathrm{C} \\
(430-890)\end{array}$ & $\begin{array}{l}770(3) \mathrm{C} \\
(570-1000)\end{array}$ & $\begin{array}{l}1100(6) \mathrm{C} \\
(620-2000)\end{array}$ & $\begin{array}{l}(2) \\
(110-240)\end{array}$ & $\mathrm{N} / \mathrm{A}^{\mathrm{e}}$ \\
\hline TEQ & $\begin{array}{l}10(6) \mathrm{A} \\
(4.2-22)\end{array}$ & $\begin{array}{l}30(6) \mathrm{A} \\
(16-57)\end{array}$ & $\begin{array}{l}150(6) \text { В } \\
(59-370)\end{array}$ & $\begin{array}{l}210(6) \mathrm{B} \\
(160-280)\end{array}$ & $\begin{array}{l}390(3) \mathrm{B} \\
(210-710)\end{array}$ & $\begin{array}{l}510(6) \mathrm{B} \\
(260-1000)\end{array}$ & $\begin{array}{l}(2) \\
(63-92)\end{array}$ & N/A \\
\hline
\end{tabular}

Note: Values (ng/kg ww) were rounded and represent only two significant figures; they are given as the geometric mean with the sample size given in parentheses $(n)$ over the $95 \%$ confidence interval

${ }^{\text {a }}$ Eggs include both live and addled eggs

${ }^{\mathrm{b}}$ Means identified with the same letter are not significantly different among locations (across) at the $p=0.05$ level using the Bonferroni means separation test

c TEQ $_{\text {WHO-Avian }}$ were calculated based on the 1998 avian WHO TEF values

${ }^{d}$ Range reported for sites with only two samples. Sites were not included in the between location statistical comparisons

${ }^{\text {e }} \mathrm{N} / \mathrm{A}=$ no samples collected from this location

$\Sigma$ PCDD/DF in eggs of tree swallows were not (Table 1). Mean concentrations of $\Sigma \mathrm{PCDD} / \mathrm{DFs}$ in house wren and eastern bluebird eggs were 10- to 19-fold and 4- to 16-fold greater at Tittabawassee River SAs than RAs, respectively, whereas house wren eggs at Saginaw River SAs tended to be intermediate between the two and comparisons at this location were not possible for eastern bluebird eggs due to a limited sample size. Maximum concentration of $\Sigma$ PCDD/ $\mathrm{DF}$ in eggs of house wrens, tree swallows, and eastern bluebirds were $7200 \mathrm{ng} / \mathrm{kg}$ at T-4, $2000 \mathrm{ng} / \mathrm{kg}$ at R-1, and $2400 \mathrm{ng} / \mathrm{kg}$ at T-6, respectively.

Concentrations of $\Sigma \mathrm{PCDD} / \mathrm{DF}$ in nestlings of house wrens, tree swallows, and eastern bluebirds were significantly different among sampling locations (Table 2). Mean concentrations of $\Sigma \mathrm{PCDD} / \mathrm{DFs}$ in house wren, tree swallow, and eastern bluebird nestlings were 15- to 49-fold, 4- to 23-fold, and 7- to 45-fold greater at Tittabawassee River SAs than RAs, respectively. House wren and tree swallow nestlings at Saginaw River SAs tended to have concentrations that were intermediate between the other two SAs. Comparisons at this area were not possible for eastern bluebird eggs due to a limited sample size. Maximum concentrations of $\Sigma \mathrm{PCDD} / \mathrm{DF}$ in nestlings of house wrens, tree swallows, and eastern bluebirds occurred at T-6 and were $1700 \mathrm{ng} / \mathrm{kg}, \quad 7300 \mathrm{ng} / \mathrm{kg}$, and $2100 \mathrm{ng} / \mathrm{kg}$, respectively.

Concentrations of $\Sigma \mathrm{PCDD} / \mathrm{DF}$ in live and addled eggs of tree swallows were significantly different at the RAs $(t=3.08, p=0.0095)$ but not at SAs. $\Sigma \mathrm{PCDD} / \mathrm{DF}$ concentrations in live and addled eggs were not significantly different for house wrens or eastern bluebirds. Tree swallow addled egg $\Sigma$ PCDD/DF concentrations were twofold greater than live eggs collected at RAs (Fig. 2).

Concentrations of $\Sigma \mathrm{PCDD} / \mathrm{DF}$ in tree swallow eggs were correlated with egg lay order $(R=0.61284, p=$ $0.0198, n=14$ ) at the RAs but not at the SAs. $\Sigma$ PCDD/DF concentrations in eggs were not correlated with egg lay order for house wrens or eastern bluebirds. The correlation between concentrations of $\Sigma \mathrm{PCDD} / \mathrm{DF}$ and date laid were only significant for tree swallow eggs at the Saginaw River SA $(R=0.56296, p=0.0452, n=13)$. Concentrations of $\Sigma \mathrm{PCDD} / \mathrm{DF}$ were individually correlated with collection day in nestlings of house wrens, tree swallows, and eastern bluebirds at RAs $(R=-0.70022, p=0.0112, n=12$; $R=0.70403, \quad p=0.0106, n=12 ; \quad R=0.68281, \quad p=$ $0.0144, n=12$; respectively), whereas all correlations 
Table 2 Total concentrations of furans and dioxins ( $\Sigma$ PCDD/DF) and TEQs ${ }_{\mathrm{WHO} \text {-Avian }}$ in nestlings ${ }^{\mathrm{a}}$ of house wrens, tree swallows, and eastern bluebirds collected during 2005-2007 from the Chippewa River, Tittabawassee River, and Saginaw River floodplains, Midland, Michigan (USA)

\begin{tabular}{|c|c|c|c|c|c|c|c|c|}
\hline & \multicolumn{2}{|c|}{ Reference area } & \multicolumn{6}{|l|}{ Study area } \\
\hline & $\mathrm{R}-1$ & $\mathrm{R}-2$ & $\mathrm{~T}-3$ & $\mathrm{~T}-4$ & $\mathrm{~T}-5$ & T-6 & S-7 & S-9 \\
\hline \multicolumn{9}{|l|}{ House wren } \\
\hline$\Sigma \mathrm{PCDD} / \mathrm{DF}$ & $\begin{array}{l}14(6) \mathrm{A}^{\mathrm{b}} \\
(9.2-21)\end{array}$ & $\begin{array}{l}24(6) \mathrm{AB} \\
(19-31)\end{array}$ & $\begin{array}{l}610(7) \mathrm{D} \\
(330-1100)\end{array}$ & $\begin{array}{l}350(7) \mathrm{CD} \\
(230-540)\end{array}$ & $\begin{array}{l}420(6) \mathrm{CD} \\
(230-760)\end{array}$ & $\begin{array}{l}530(6) \mathrm{CD} \\
(270-1000)\end{array}$ & $\begin{array}{l}180(6) \mathrm{C} \\
(83-410)\end{array}$ & $\begin{array}{l}55(4) \mathrm{B} \\
(33-90)\end{array}$ \\
\hline 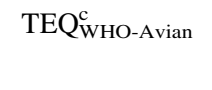 & $\begin{array}{l}3.4(6) \mathrm{A} \\
(1.7-6)\end{array}$ & $\begin{array}{l}6.5(6) \mathrm{AB} \\
(5.7-7.5)\end{array}$ & $\begin{array}{l}290(7) \mathrm{D} \\
(140-580)\end{array}$ & $\begin{array}{l}140(7) \mathrm{CD} \\
(110-180)\end{array}$ & $\begin{array}{l}210(6) \mathrm{CD} \\
(93-460)\end{array}$ & $\begin{array}{l}300(6) \mathrm{D} \\
(140-660)\end{array}$ & $\begin{array}{l}78(6) \mathrm{C} \\
(34-180)\end{array}$ & $\begin{array}{l}18(4) \mathrm{B} \\
(14-22)\end{array}$ \\
\hline \multicolumn{9}{|l|}{ Tree swallow } \\
\hline$\Sigma \mathrm{PCDD} / \mathrm{DF}$ & $\begin{array}{l}64(6) \mathrm{A} \\
(32-130)\end{array}$ & $\begin{array}{l}110(6) \mathrm{AB} \\
(81-140)\end{array}$ & $\begin{array}{l}460(6) \mathrm{CD} \\
(320-670)\end{array}$ & $\begin{array}{l}460(6) \mathrm{CD} \\
(320-660)\end{array}$ & $\begin{array}{l}360(3) \mathrm{C} \\
(74-1700)\end{array}$ & $\begin{array}{l}1100(6) \mathrm{D} \\
(390-3000)\end{array}$ & $\begin{array}{l}270(6) \mathrm{BC} \\
(180-410)\end{array}$ & $\begin{array}{l}250(6) \mathrm{BC} \\
(190-350)\end{array}$ \\
\hline TEQ $_{\text {who-Avian }}$ & $\begin{array}{l}25(6) \mathrm{A} \\
(16-36)\end{array}$ & $\begin{array}{l}47(6) \mathrm{A} \\
(42-52)\end{array}$ & $\begin{array}{l}340(6) \mathrm{BC} \\
(230-500)\end{array}$ & $\begin{array}{l}320(6) \mathrm{BC} \\
(210-500)\end{array}$ & $\begin{array}{l}240(3) \mathrm{B} \\
(54-1100)\end{array}$ & $\begin{array}{l}860(6) \mathrm{C} \\
(310-2400)\end{array}$ & $\begin{array}{l}190(6) \mathrm{B} \\
(120-320)\end{array}$ & $\begin{array}{l}150(6) \mathrm{B} \\
(100-210)\end{array}$ \\
\hline \multicolumn{9}{|l|}{ Eastern bluebird } \\
\hline$\Sigma \mathrm{PCDD} / \mathrm{DF}$ & $\begin{array}{l}24(6) \mathrm{A} \\
(12-48)\end{array}$ & $\begin{array}{l}41(6) \mathrm{A} \\
(22-75)\end{array}$ & $\begin{array}{l}520(6) \mathrm{BC} \\
(260-1000)\end{array}$ & $\begin{array}{l}330(5) \mathrm{B} \\
(180-590)\end{array}$ & $N / A^{d}$ & 1200 (5) C & $\begin{array}{l}(2) \\
(150-152)^{\mathrm{e}}\end{array}$ & N/A \\
\hline TEQ $_{\text {who-Avian }}$ & $\begin{array}{l}2.8(6) \mathrm{A} \\
(2-3.7)\end{array}$ & $\begin{array}{l}7.6(6) \mathrm{A} \\
(4.9-11)\end{array}$ & $\begin{array}{l}190(6) \mathrm{B} \\
(65-570)\end{array}$ & $\begin{array}{l}100(5) \mathrm{B} \\
(50-210)\end{array}$ & N/A & $\begin{array}{l}690(5) \mathrm{C} \\
(300-1600)\end{array}$ & $\begin{array}{l}(2) \\
(49-70)\end{array}$ & N/A \\
\hline
\end{tabular}

Note: Values (ng/kg ww) were rounded and represent only two significant figures; they are given as the geometric mean with the sample size given in parentheses $(n)$ over the $95 \%$ confidence interval

${ }^{\text {a }}$ House wren nestlings were collected on day 10 and tree swallow and eastern bluebird nestlings were collected on day 14 (hatch $=$ day 0 )

b Means identified with the same letter are not significantly different among locations (across) at the $p=0.05$ level using the Bonferroni means separation test

c TEQ $_{\text {WHO-Avian }}$ were calculated based on the 1998 avian WHO TEF values

${ }^{\mathrm{d}} \mathrm{N} / \mathrm{A}=$ no samples collected from this location

e Range reported for sites with only two samples. Sites were not included in the between location statistical comparisons

were not significant at downstream SAs. For the clutches analyzed, the within-clutch variability of concentrations of $\Sigma$ PCDD/DF in eggs varied by only $10-38 \%$ across species and sites (Table 3 ).

Concentrations of $\Sigma$ PCBs in eggs were greatest for tree swallows, intermediate for house wrens, and least for eastern bluebirds (Table 4). Concentrations of $\Sigma$ DDXs were greatest in tree swallow eggs and were primarily composed of $4^{\prime}, 4^{\prime}$-dichloro-diphenyl-dichloroethylene (Table 4).

\section{TCDD Equivalents $\left(\mathrm{TEQ}_{\mathrm{WHO}-\mathrm{Avian}}\right)$}

The $\mathrm{TEQ}_{\mathrm{WHO}-\mathrm{Avian}}$ concentrations in eggs or nestlings were not different among years, but $\mathrm{TEQ}_{\mathrm{WHO}-\mathrm{Avian}}$ concentrations did vary between eggs and nestlings as well as among species and locations. Because there was no statistically significant difference in $\mathrm{TEQ}_{\mathrm{WHO}}$-Avian concentrations among years $(F=2.48, p=0.0855)$ data were pooled across years and comparisons were made by species $(F=26.18, p<0.0001)$ and sample type $(F=34.02$, $p<0.0001)$ when comparing among sampling locations $(F=66.62, p<0.0001)$.

The TEQ ${ }_{\text {WHO-Avian }}$ concentrations in eggs of both house wrens and eastern bluebirds were significantly different among sampling locations, whereas TEQ centrations in eggs of tree swallows were not (Table 1). Mean TEQ ${ }_{W H O-A v i a n}$ concentrations in house wren and eastern bluebird eggs were 15- to 91-fold and 5- to 46-fold greater at Tittabawassee River SAs than RAs, respectively, whereas concentrations in house wren eggs at Saginaw River SAs tended to be intermediate between the two and comparisons at this location were not possible for eastern bluebird eggs due to a limited sample size. Maximum TEQwHO-Avian concentrations in eggs of house wrens, tree swallows, and eastern bluebirds were $2300 \mathrm{ng} / \mathrm{kg}$ at $\mathrm{T}-3$, $730 \mathrm{ng} / \mathrm{kg}$ at R-1, and $1000 \mathrm{ng} / \mathrm{kg}$ at T-6, respectively.

Concentrations of $\mathrm{TEQ}_{\mathrm{WHO}-\mathrm{Avian}}$ in nestlings of house wrens, tree swallows, and eastern bluebirds were significantly different among sampling locations (Table 2). Mean TEQ ${ }_{W H O-A v i a n}$ concentrations in house wrens, tree swallows, and eastern bluebirds nestlings were 21- to 105-fold, 6- to 58-fold, and 15- to 276-fold greater at Tittabawassee River SAs than RAs, respectively, whereas house wren and tree swallow nestlings at Saginaw River SAs tended to be intermediate between the other two SAs and comparisons at this area were not possible for eastern bluebird eggs due to a limited sample size. Maximum TEQ ${ }_{W H O-A v i a n}$ concentrations in nestlings of house wrens, tree swallows, and eastern 
Fig. 2 Range and mean of $\Sigma \mathrm{PCDD} / \mathrm{DF}$ concentrations in live and addled eggs of house wrens, tree swallows, and eastern bluebirds collected in 2005-2007 near Midland, Michigan. Sample size is indicated for each area with at least two samples collected. R-1 to $\mathrm{R}-2=$ reference areas; $\mathrm{T}-3$ to T-6 = Tittabawassee River study areas; S-7 and S-

$9=$ Saginaw River study areas; $* p<0.05$

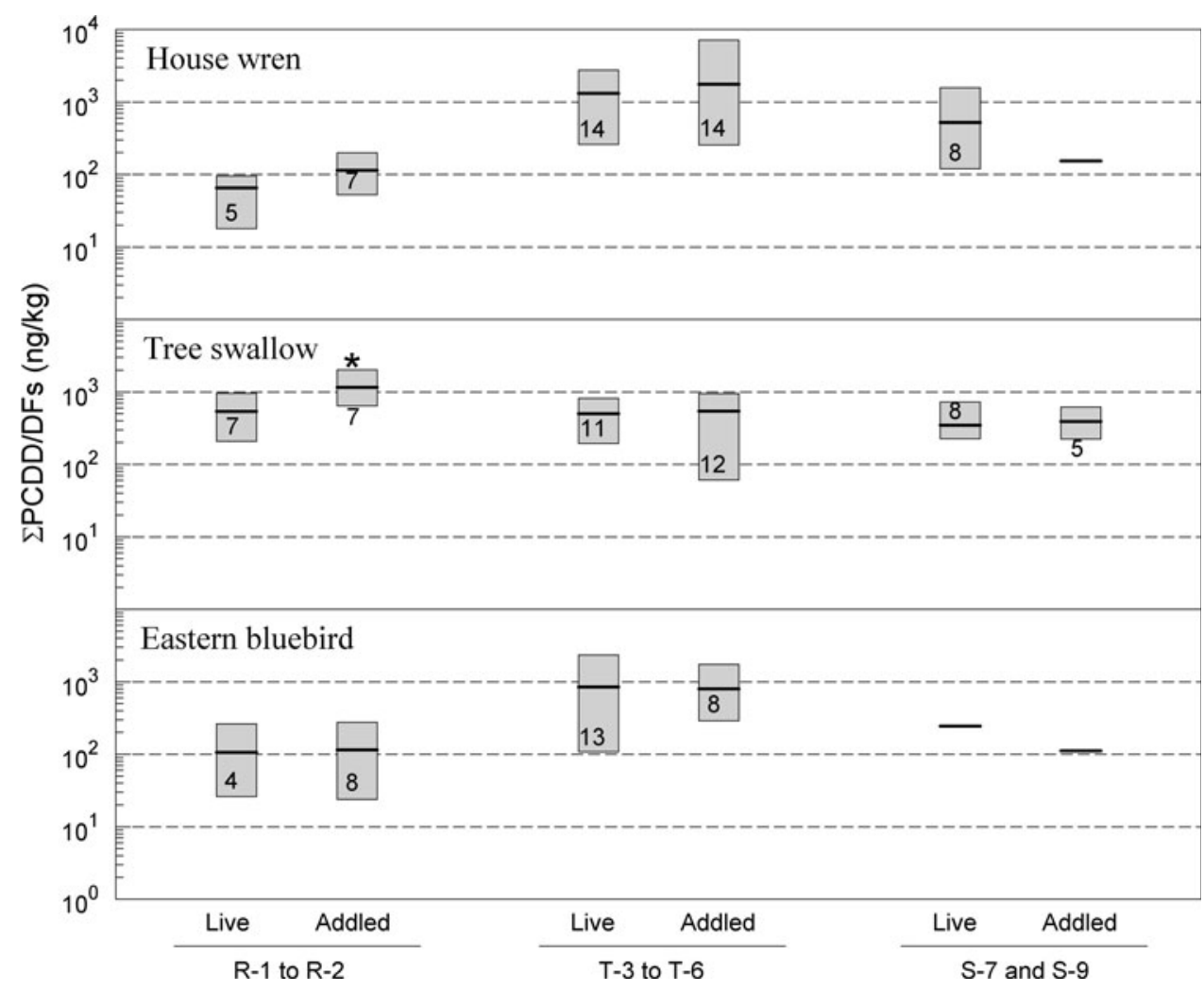

bluebirds occurred at T-6 and were $1200 \mathrm{ng} / \mathrm{kg}, 6000 \mathrm{ng} / \mathrm{kg}$, and $1400 \mathrm{ng} / \mathrm{kg}$, respectively.

Concentrations of TEQ ${ }_{w H O}$-Avian in live and addled eggs exhibited the same trends as concentrations of $\Sigma \mathrm{PCDD} / \mathrm{DF}$ (Fig. 2) for all studied species. TEQ ${ }_{\mathrm{WHO} \text {-Avian }}$ concentrations in addled tree swallow eggs were greater than in live eggs at RAs $(t=3.52, p=0.0042)$. Concentrations of TEQ ${ }_{\text {WHO-Avian }}$ in tree swallow eggs were correlated with egg lay order $(R=0.60047, p=0.0232, n=14)$ at the RAs but not at the SAs. TEQwHO-Avian concentrations in eggs of house wrens and eastern bluebirds were not correlated with egg lay order. Concentrations of TEQ Avian in eggs and nestlings of all species were not correlated with date laid or collection day, respectively, across all areas. For the clutches analyzed, the within-clutch variability of concentrations of TEQ ${ }_{\text {WHO-Avian }}$ in eggs varied by only $7-42 \%$ across species and sites (Table 3 ). Concentrations of $\Sigma \mathrm{PCB} \mathrm{TEQ}_{\mathrm{WHO}}$-Avian in eggs of tree swallows comprised from 23 to $47 \%$ of the $\Sigma T E Q_{w H O-A v i a n}$, whereas in house wren and eastern bluebird eggs $\Sigma$ PCB TEQ ${ }_{W H O-A v i a n}$ concentrations only comprised $<1-8 \%$ (Table 4).

\section{Congener Patterns}

Relative proportions of PCDD/DF concentrations contributed by individual congeners varied between the eggs and nestlings as well as among species and sampling areas. Congener profiles were characterized by principle component analysis (PCA) by relative orderings of PCDD/DF concentrations normalized to the $\Sigma \mathrm{PCDD} / \mathrm{DF}$ concentration. The PCA model that included two principle components (PC1 and $\mathrm{PC} 2$ ) explained $85 \%$ of the total variance. All samples collected in RAs had negative greatest eigenvectors for both $\mathrm{PC} 1$ and $\mathrm{PC} 2$, whereas tree swallow samples were separated by positive vectors for PC1 (loading score of 0.89 for 2,3,7,8-TCDF). House wren and eastern bluebird had positive vectors for PC2 (loading score of 0.84 for 2,3,4,7,8-PeCDF) and negative vectors for PC1 (Fig. 3).

For all three species, dioxins dominated the congener profile at RAs and furans dominated at the SAs. For example, at RAs, tree swallow mean egg PCDD/DF concentration congener profiles were dominated by $79 \%$ dioxin congeners compared to SAs that only had 44\% (Fig. 4). For all species studied, congener profiles of eggs and nestlings at Saginaw River SAs were similar to those at Tittabawassee River SAs (supplemental information in Fig. 6). Mean PCDD/DF congener profiles of egg and nestling house wrens and eastern bluebirds were dominated by a combination of 2,3,7,8-TCDF and 2,3,4,7,8-PeCDF at Tittabawassee River SAs (Fig. 4). An even larger proportion of the total was 2,3,7,8-TCDF and 2,3,4,7,8-PeCDF for tree swallows at the SAs. Mean nestling PCDD/DF concentration congener profiles for all species at Tittabawassee River SAs were 
Table 3 Within-clutch variability of total concentrations of furans and dioxins ( $\mathrm{PCDD} / \mathrm{DF})$ and TEQs $\mathrm{s}_{\mathrm{WHO}-\mathrm{A} \text { vian }}^{\mathrm{a}}$ in eggs of house wrens, tree swallows, and eastern bluebirds collected during 2005-2007 from the Chippewa River and Tittabawassee River floodplains, Midland, Michigan (USA)

\begin{tabular}{|c|c|c|c|c|c|c|c|c|}
\hline & Clutch initiation $^{\mathrm{b}}$ & Site $^{c}$ & $\mathrm{E} 1^{\mathrm{d}, \mathrm{e}}$ & E2 & E3 & E4 & E5 & $\begin{array}{l}\text { Percent } \\
\text { difference }^{f}\end{array}$ \\
\hline \multicolumn{9}{|c|}{ House wren } \\
\hline \multirow[t]{2}{*}{ Clutch 1} & \multirow[t]{2}{*}{21 Jun 06} & \multirow[t]{2}{*}{$\mathrm{R}-1$} & $240(\mathrm{LE})^{\mathrm{g}}$ & $150(\mathrm{AE})$ & $200(\mathrm{AE})$ & & & 37 \\
\hline & & & $51(2)^{\mathrm{h}}$ & $32(5)$ & $30(7)$ & & & 41 \\
\hline \multirow[t]{2}{*}{ Clutch 2} & \multirow[t]{2}{*}{10 May 06} & \multirow[t]{2}{*}{$\mathrm{R}-1$} & 77 (LE) & $73(\mathrm{AE})$ & $60(\mathrm{AE})$ & & & 21 \\
\hline & & & $8.4(1)$ & $8.2(3)$ & $9.6(5)$ & & & 15 \\
\hline \multirow[t]{2}{*}{ Clutch 3} & \multirow[t]{2}{*}{03 Jun 07} & \multirow[t]{2}{*}{$\mathrm{T}-4$} & $1400(\mathrm{AE})$ & $1600(\mathrm{AE})$ & $1700(\mathrm{AE})$ & & & 19 \\
\hline & & & $630(1)$ & $480(3)$ & $780(4)$ & & & 39 \\
\hline \multirow[t]{2}{*}{ Clutch 4} & \multirow[t]{2}{*}{24 May 06} & \multirow[t]{2}{*}{$\mathrm{T}-5$} & $330(\mathrm{AE})$ & $320(\mathrm{AE})$ & $240(\mathrm{AE})$ & $250(\mathrm{AE})$ & & 27 \\
\hline & & & $140(1)$ & $140(3)$ & $100(4)$ & $100(5)$ & & 28 \\
\hline \multicolumn{9}{|c|}{ Tree swallow } \\
\hline \multirow[t]{2}{*}{ Clutch 1} & \multirow[t]{2}{*}{09 May 06} & \multirow[t]{2}{*}{$\mathrm{R}-1$} & 430 (LE) & 370 (LE) & 330 (LE) & & & 23 \\
\hline & & & $120(1)$ & $110(2)$ & $110(3)$ & & & 7 \\
\hline \multirow[t]{2}{*}{ Clutch 2} & \multirow[t]{2}{*}{30 May 05} & \multirow[t]{2}{*}{$\mathrm{R}-2$} & $510(\mathrm{LE})$ & $550(\mathrm{AE})$ & $660(\mathrm{AE})$ & 740 (AE) & 780 (AE) & 34 \\
\hline & & & $270(1)$ & $290(2)$ & $340(3)$ & $370(4)$ & $370(5)$ & 27 \\
\hline \multirow[t]{2}{*}{ Clutch 3} & \multirow[t]{2}{*}{08 May 06} & \multirow[t]{2}{*}{$\mathrm{T}-3$} & $690(\mathrm{AE})$ & 670 (LE) & $560(\mathrm{AE})$ & & & 20 \\
\hline & & & $210(1)$ & $210(2)$ & $190(3)$ & & & 9 \\
\hline \multirow[t]{2}{*}{ Clutch 4} & \multirow[t]{2}{*}{19 May 06} & \multirow[t]{2}{*}{$\mathrm{T}-6$} & $1000(\mathrm{AE})$ & $1500(\mathrm{AE})$ & $1700(\mathrm{AE})$ & & & 38 \\
\hline & & & $690(2)$ & $1100(3)$ & $1200(4)$ & & & 42 \\
\hline \multicolumn{9}{|c|}{ Eastern bluebird } \\
\hline \multirow[t]{2}{*}{ Clutch 1} & \multirow[t]{2}{*}{02 Jun 06} & \multirow[t]{2}{*}{$\mathrm{R}-1$} & $24(\mathrm{AE})$ & 25 (AE) & 24 (AE) & 27 (AE) & & 14 \\
\hline & & & $6.8(1)$ & $6.4(2)$ & $5.9(3)$ & $6.4(4)$ & & 14 \\
\hline Clutch 2 & 30 May 07 & $\mathrm{R}-2$ & $120(\mathrm{AE})$ & 99 (AE) & 87 (AE) & & & 25 \\
\hline & & & $28(1)$ & $27(3)$ & $25(5)$ & & & 9 \\
\hline Clutch 3 & 14 May 06 & T-3 & 380 (LE) & 390 (LE) & 360 (LE) & 350 (LE) & 380 (LE) & 29 \\
\hline & & & $170(1)$ & $170(2)$ & $170(3)$ & $160(4)$ & $180(5)$ & 38 \\
\hline Clutch 4 & 27 Apr 07 & $\mathrm{~T}-3$ & $210(\mathrm{AE})$ & $300(\mathrm{AE})$ & $280(\mathrm{AE})$ & & & 10 \\
\hline & & & $100(1)$ & $170(4)$ & $160(4)$ & & & 9 \\
\hline Clutch 5 & 01 Aug 05 & T-6 & 1400 (AE) & $1600(\mathrm{AE})$ & 1400 (AE) & & & 11 \\
\hline & & & $1000(2)$ & $1200(2)$ & $1000(3)$ & & & 11 \\
\hline
\end{tabular}

Note: $\Sigma \mathrm{PCDD} / \mathrm{DF}\left(\mathrm{ng} / \mathrm{kg}\right.$ ww) with egg type given in parentheses over TEQ ${ }_{\mathrm{WHO}}$-Avian with egg number laid given in parentheses

a ${ }^{\text {TEQ }}$ wHO-Avian were calculated based on the 1998 avian WHO TEF values

${ }^{\mathrm{b}}$ Clutch initiation is the day the first egg was discovered

c R-1 to R-2 are reference areas and T-3 to T-6 are Tittabawassee River study areas

${ }^{\mathrm{d}}$ Values were rounded and represent only two significant figures

e E1-E5 indicate individual eggs analyzed per clutch

${ }^{\mathrm{f}}$ Percent difference is calculated as the maximum value minus the minimum divided by the maximum times 100 for each clutch (prior to rounding)

g Egg type: $\mathrm{LE}=$ live egg and $\mathrm{AE}=$ addled egg

${ }^{\mathrm{h}}$ Egg \#: Numbered in order as laid starting with 1. If two eggs have the same number, they were both found new, so lay order is unknown

composed of between 69 and $84 \%$ furan congeners, with 2,3,7,8-TCDF and 2,3,4,7,8-PeCDF making up $35-60 \%$ of the total. The majority of congeners were above the detection limit in over $50 \%$ of samples with the exception of the dioxinlike congeners 1,2,3,7,8,9-hexachlorodibenzofuran, 1,2,3,4,7, 8,9-heptachlorodibenczofuran, 1,2,3,4, 6,7,8,9-octachlorodibenzofuran (supplemental information: Tables 5-10). 
Table 4 Concentrations of selected co-contaminants in eggs of house wrens, tree swallows, and eastern bluebirds collected during 2005-2007 from the Chippewa and Tittabawassee River floodplains, Midland, Michigan (USA)

\begin{tabular}{|c|c|c|c|c|c|c|c|c|c|c|}
\hline & Site $^{\mathrm{a}}$ & Egg type $^{b}$ & $\operatorname{Egg} \#^{c}$ & $\begin{array}{l}\Sigma P C B s \\
\text { TEQs }^{\mathrm{d}, \mathrm{e}}\end{array}$ & $\begin{array}{l}\Sigma \mathrm{PCDD} / \mathrm{DFs} \\
\text { TEQs }\end{array}$ & $\Sigma \mathrm{PCBs}^{\mathrm{f}}$ & $2^{\prime} 4^{\prime}$-DDT & $4^{\prime} 4^{\prime}-\mathrm{DDE}$ & $4^{\prime} 4^{\prime}$-DDT & $\Sigma$ DDXs \\
\hline \multicolumn{11}{|l|}{ House wren } \\
\hline Sample $1^{\mathrm{g}}$ & $\mathrm{T}-3$ & LE & 1 & 12 & 620 & $1.3 \mathrm{E}^{\mathrm{h}}-2$ & $6.4 \mathrm{E}-5$ & $6.6 \mathrm{E}-2$ & $8.9 \mathrm{E}-4$ & $6.7 \mathrm{E}-2$ \\
\hline Sample 2 & $\mathrm{~T}-4$ & $\mathrm{AE}$ & 2 & 8.0 & 180 & $3.5 \mathrm{E}-2$ & $4.7 \mathrm{E}-5$ & $3.0 \mathrm{E}-2$ & $2.9 \mathrm{E}-4$ & $3.1 \mathrm{E}-2$ \\
\hline \multicolumn{11}{|l|}{ Tree swallow } \\
\hline Sample 1 & $\mathrm{R}-2$ & LE & 1 & 62 & 110 & $2.1 \mathrm{E}-2$ & $1.1 \mathrm{E}-3$ & $1.3 \mathrm{E}-1$ & $4.2 \mathrm{E}-3$ & $1.4 \mathrm{E}-1$ \\
\hline Sample 2 & $\mathrm{~T}-4$ & $\mathrm{AE}$ & 5 & 520 & 580 & $2.3 \mathrm{E}-1$ & 7.4E-4 & $2.7 \mathrm{E}-1$ & 7.0E-3 & $2.8 \mathrm{E}-1$ \\
\hline Sample 3 & $\mathrm{~T}-6$ & LE & 3 & 160 & 540 & $8.0 \mathrm{E}-2$ & 4.4E-5 & 7.2E-1 & $1.7 \mathrm{E}-3$ & 7.2E-1 \\
\hline \multicolumn{11}{|c|}{ Eastern bluebird } \\
\hline Sample 1 & $\mathrm{R}-1$ & $\mathrm{AE}$ & 1 & 0.57 & 6.8 & $1.3 \mathrm{E}-3$ & $2.8 \mathrm{E}-5$ & $1.0 \mathrm{E}-2$ & $2.3 \mathrm{E}-4$ & $1.0 \mathrm{E}-2$ \\
\hline Sample 2 & $\mathrm{R}-2$ & $\mathrm{AE}$ & 3 & 0.73 & 27 & $3.7 \mathrm{E}-3$ & $2.0 \mathrm{E}-5$ & $1.8 \mathrm{E}-1$ & $8.2 \mathrm{E}-4$ & $1.8 \mathrm{E}-1$ \\
\hline Sample 3 & $\mathrm{~T}-3$ & LE & 1 & 0.68 & 170 & $2.6 \mathrm{E}-3$ & $9.0 \mathrm{E}-6$ & $6.8 \mathrm{E}-2$ & $3.9 \mathrm{E}-3$ & 7.1E-2 \\
\hline Sample 4 & $\mathrm{~T}-3$ & $\mathrm{AE}$ & 4 & 0.73 & 170 & $5.1 \mathrm{E}-3$ & $1.6 \mathrm{E}-5$ & 7.2E-2 & $1.5 \mathrm{E}-3$ & 7.4E-2 \\
\hline Sample 5 & T-6 & LE & 2 & 0.93 & 540 & $6.1 \mathrm{E}-3$ & $2.0 \mathrm{E}-5$ & $1.6 \mathrm{E}-1$ & $3.3 \mathrm{E}-3$ & $1.6 \mathrm{E}-1$ \\
\hline Sample 6 & T-6 & $\mathrm{AE}$ & 2 & 2.1 & 1000 & $6.2 \mathrm{E}-3$ & $2.5 \mathrm{E}-5$ & 7.7E- 2 & $8.3 \mathrm{E}-4$ & $7.8 \mathrm{E}-2$ \\
\hline
\end{tabular}

Note: Values of TEQs $\mathrm{wHO}_{\mathrm{W} \text {-Avian }}$ are presented in $\mathrm{ng} / \mathrm{kg} \mathrm{ww}$ and PCBs and DDXs are presented in $\mathrm{mg} / \mathrm{kg} \mathrm{ww}$. $\Sigma$ DDXs $=$ sum of dichlorodiphenyl-trichloroethane $\left(2^{\prime}, 4^{\prime}\right.$ and $4^{\prime}, 4^{\prime}$ DDT isomers $)$ and dichloro-diphenyl-dichloroethylene $\left(4^{\prime}, 4^{\prime}\right.$-DDE)

${ }^{\text {a }}$ R-1 to R-2 are reference areas and T-3 to T-6 are Tittabawassee River study areas

${ }^{\mathrm{b}}$ Egg type: $\mathrm{LE}=$ live egg and $\mathrm{AE}=$ addled egg

${ }^{c}$ Egg \#: Numbered in order as laid starting with 1. R-1 to R-2 are reference areas and T-3 to T-6 are Tittabawassee River study areas

${ }^{\mathrm{d}}$ Values were rounded and represent only two significant figures

e TEQ ${ }_{\text {WHO-Avian }}$ were calculated based on the 1998 avian WHO TEF values

${ }^{f} \Sigma$ PCBs included only the 12 non- and mono-ortho-substituted congeners

$\mathrm{g}$ Each sample is an individual egg from unique clutches

${ }^{\mathrm{h}} \mathrm{E}=\times 10^{n}$

\section{Discussion}

\section{$\Sigma \mathrm{PCDD} / \mathrm{DF}, \Sigma \mathrm{PCB}$, and $\Sigma \mathrm{DDX}$ Concentrations}

Concentrations of $\Sigma \mathrm{PCDD} / \mathrm{DF}$ in all passerine tissues collected except tree swallow eggs were greatest at Tittabawassee River SAs, whereas those from Saginaw River SAs had intermediate concentrations and those from RAs had the least. Concentrations of $\Sigma \mathrm{PCDD} / \mathrm{DF}$ in tree swallow eggs were similar among reference and study areas. Most accumulation studies of chlorinated hydrocarbon residues in passerines included PCBs and DDXs. A single study investigated 2,3,7,8-TCDD exposure in tree swallow tissues (Custer et al. 2005). Mean concentrations of 2,3,7,8TCDD in eggs and nestlings of tree swallows collected from contaminated areas in the Woonasquatucket River floodplain, Rhode Island (USA) ranged from 310 to 1000 and 570 to $990 \mathrm{ng} / \mathrm{kg} \mathrm{ww}$, respectively (Custer et al. 2005) and were similar to the $\Sigma \mathrm{PCDD} / \mathrm{DF}$ concentrations in eggs and nestlings for all three species from the current study. The same study reported a maximum concentration of $2,3,7,8$-TCDD in a tree swallow nestling that was four times less than the maximum level of $\Sigma \mathrm{PCDD} / \mathrm{DF}$ observed in the current study: $7300 \mathrm{ng} / \mathrm{kg}$ in a tree swallow nestling collected at T-6. To our knowledge, this sample contains the greatest measured concentration of $\Sigma \mathrm{PCDD} / \mathrm{DF}$ reported in passerine bird tissues.

Similar concentrations of $\Sigma \mathrm{PCDD} / \mathrm{DF}$ in eggs of tree swallows at RAs and SAs from the current study do not align with site-specific sediment trends. In contrast, $\Sigma$ PCDD/DF concentrations in tree swallow nestlings collected in the same areas mirror the site-specific sediment trends, as expected. These results are similar to those for $\Sigma$ PCB concentrations in tree swallow eggs collected from an upstream reference site along the Champlain Canal that were similar to those collected from downstream sites with known contamination along the Hudson River, New York (USA) (Secord et al. 1999). In that study, concentrations in nestlings were less at reference areas, which is similar to the findings in the current study. One possible explanation for these observations is that migrating swallows follow aquatic systems (Butler 1988) and could accumulate PCDD/DFs in route. Maternal contaminant deposition from body burdens 


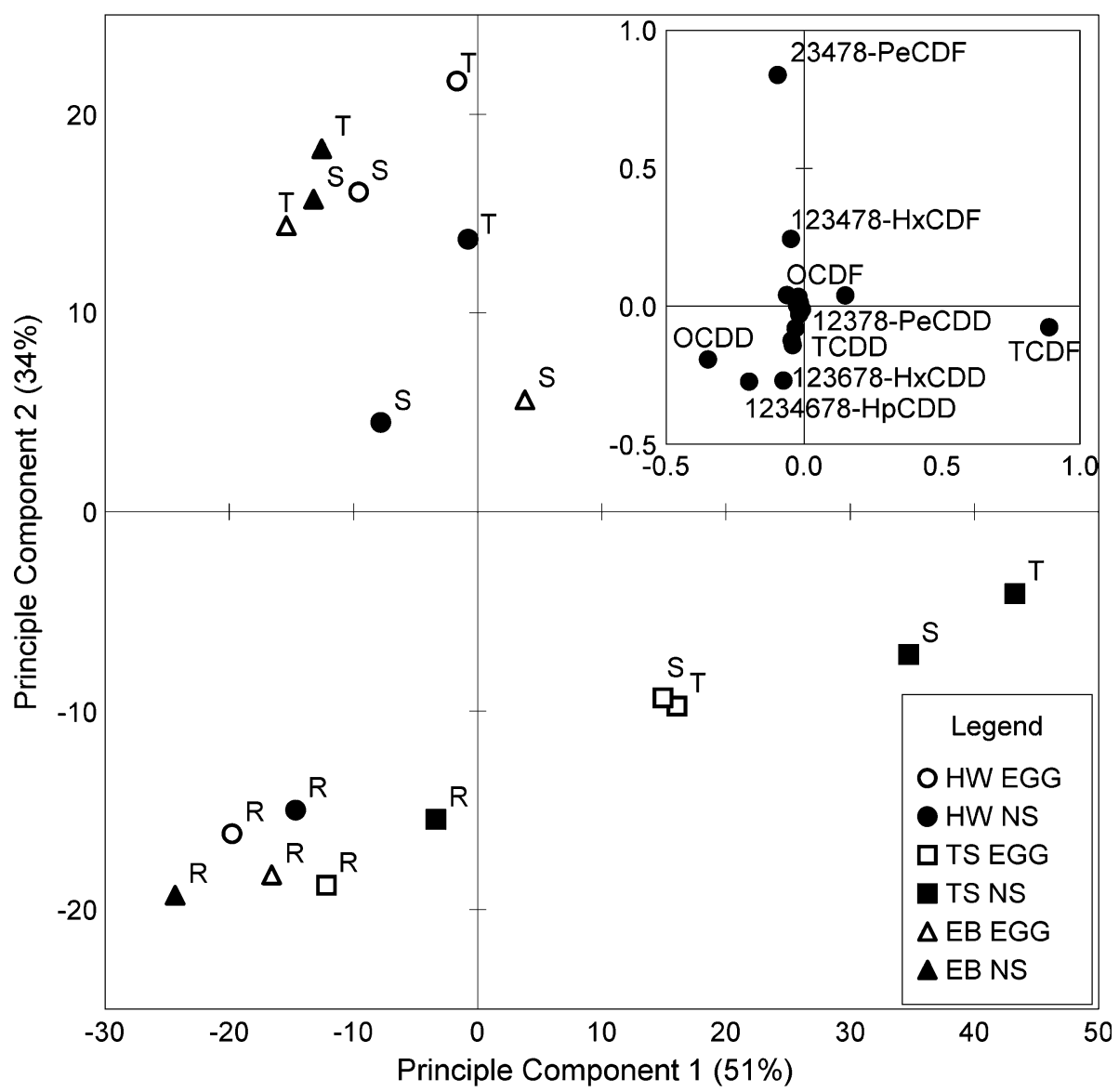

Fig. 3 PCA of PCDD/DF concentration congener profiles in eggs and nestlings of house wrens (HW), tree swallows (TS), and eastern bluebirds (EB) collected in 2005-2007 near Midland, Michigan. Individual PCDD/DF congener loading scores for each principle component is depicted in the inset. $\mathrm{R}=$ reference area; $\mathrm{T}=$ Tittabawassee River study area; $\mathrm{S}=$ Saginaw River study

might provide another explanation. Maternal transfer of contaminants to eggs has been shown to vary depending on overwintering areas in black-crowned night-herons (Henny and Blus 1986). Thus, adult female tree swallows could be exposed to concentrations of $\Sigma \mathrm{PCDD} / \mathrm{DF}$ along migration or on wintering grounds universally, but previous research demonstrated that ring-necked pheasant hens (Phasianus colchicus) were only able to translocate $\sim 1 \%$ of their cumulative dosage amount to each egg (Nosek et al. 1992b). Because the congener profiles in tree swallow eggs were different between RAs and SAs, the most plausible possibility is that, prior to breeding, foraging ranges of swallows at upstream RAs temporarily include a proximal contaminated site. This explanation seems most reasonable because adult tree swallows arrive at breeding areas to defend breeding territories several weeks prior to clutch initiation (Stutchbury and Robertson 1987) and have slightly larger foraging ranges than during area; $\quad$ TCDF $=$ tetrachlorodibenzofuran $; \quad$ PeCDF $=$ pentachlorodibenzofuran; $\mathrm{HxCDF}=$ hexachlorodibenzofuran; $\mathrm{HpCDF}=$ heptachlorodibenzofuran; $\quad$ OCDF $=$ octachlorodibenzofuran; $\quad$ TCDD = tetrachlorodibenzo- $p$-dioxin; PeCDD = pentachlorodibenzo- $p$-dioxin; $\mathrm{HxCDD}=$ hexachlorodibenzo- $p$-dioxin; HpCDD = heptachlorodibenzop-dioxin; OCDD $=$ octachlorodibenzo- $p$-dioxin

brood rearing (Quinney and Ankney 1985). Additionally, most passerines are considered income-breeders (meaning that the majority of resources for egg production are acquired through the daily diet during egg development), and this further confirms the hypothesis that tree swallow females are likely traveling to a proximal contaminated site during egg production at RAs (Langin et al. 2006; Nager 2006).

The $\Sigma$ PCDD/DF concentrations in live and addled eggs were similar for all areas, with the exception of tree swallow eggs in the RAs. Addled eggs (arithmetic mean: $5.2 \% ; n=63)$ had significantly lower $(t=-2.67$, $p=0.0085)$ percent lipids compared to live eggs $(6.1 \%$, $n=71$ ); however, this small difference can be attributed to partial embryo development in addled eggs. A greater percent lipids in addled eggs would have been expected if differences between fresh and addled eggs were due to desiccation. Comparisons of $\Sigma \mathrm{PCDD} / \mathrm{DF}$ concentrations 


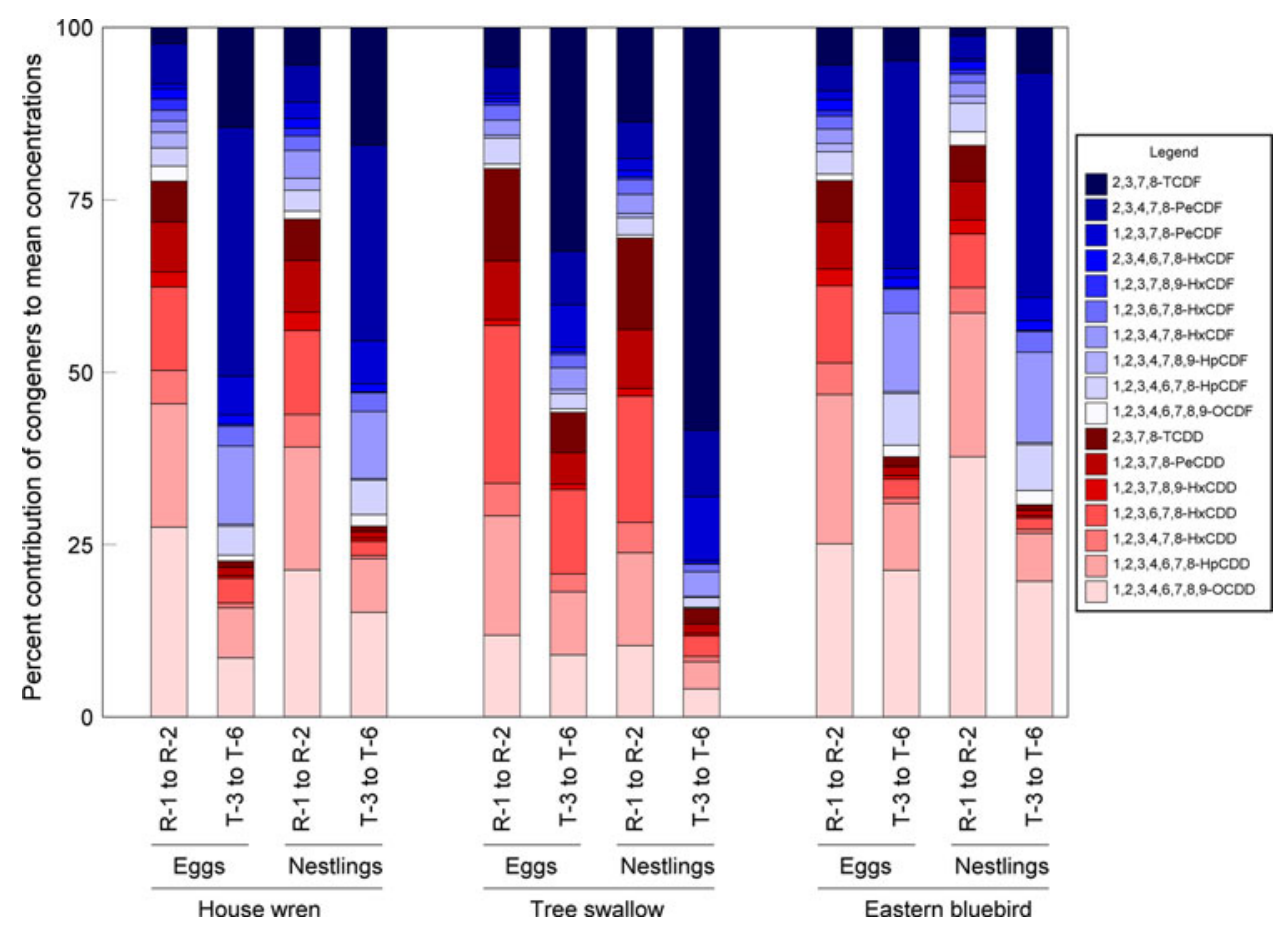

Fig. 4 Mean congener percent contributions in eggs and nestlings of house wrens, tree swallows, and eastern bluebirds collected in 20052007 near Midland, Michigan. R-1 to R-2 = reference area; T-3 to T$6=$ Tittabawassee River study area; $\mathrm{TCDF}=$ tetrachlorodibenzofuran; $\mathrm{PeCDF}=$ pentachlorodibenzofuran; $\mathrm{HxCDF}=$ hexachlorodi-

in live and addled eggs could provide insight into exposure concentrations at which eggs lose viability. However, metabolism of these compounds by the developing embryo can result in differences that are an artifact of embryo survival rather than fecundity. Recent egg injection studies have noted significant embryo metabolism of one of the major site-related PCDF congeners (M. J. Zwiernik, personal communication). Based on comparisons of congener specific adult biomagnification factors in herring gulls (Larus argentatus), TCDF was determined to be rapidly metabolized as opposed to 2,3,4,7,8-PeCDF, for which metabolism was determined to be variable and possibly linked to speciesspecific differences in distribution or metabolism (Braune and Norstrom 1989). Previous research on mallards (Anas platyrhynchos; Norstrom et al. 1976) and bald eagles (Haliaeetus leucocephalus; Elliott et al. 1996) have discussed similar trends in metabolism for PCDF congeners. Furthermore, concentrations of $\Sigma$ PCBs in live and addled eggs were not different for tree swallows exposed to PCBs in the Kalamazoo River floodplain, Michigan (USA) (Neigh et al. 2006b). In addition, the concentration of $\Sigma$ PCDD/DF in eggs of tree swallows at RAs in both live and addled eggs from the current study benzofuran; $\mathrm{HpCDF}=$ heptachlorodibenzofuran; OCDF $=$ octachlorodibenzofuran; $\quad$ TCDD $=$ tetrachlorodibenzo- $p$-dioxin; $\quad$ PeCDD $=$ pentachlorodibenzo- $p$-dioxin; HxCDD = hexachlorodibenzo- $p$-dioxin; $\mathrm{HpCDD}=$ heptachlorodibenzo- $p$-dioxin; OCDD $=$ octachlorodibenzo-p-dioxin

were below a predicted threshold of effects (Custer et al. 2005).

Concentrations of $\Sigma \mathrm{PCDD} / \mathrm{DF}$ and the lay or collection day for eggs of all species at RAs and nestlings of tree swallows at Saginaw River SAs were significantly correlated. Examining the data further revealed that the marginal correlations, with coefficients of determination $\left(r^{2}\right)$ ranging from 0.32 to 0.49 , were spurious and not indicative of true temporal trends in the concentrations. It was hypothesized that eggs laid or nestlings collected later in the nesting season would have stable or lesser concentrations at RAs and greater concentrations at SAs corresponding to extended site-specific exposure. The eggs of house wrens at RAs had a negative correlation, as expected, but it was influenced by small sample size late in the season. Additionally, if the correlations were valid, similar correlations could have been expected for concentrations of $\mathrm{TEQ}_{\mathrm{WHO}}$-Avian, but none were observed.

Concentrations of $\Sigma$ PCDD/DF in multiple eggs from the same nesting attempt were measured for all three species to investigate possible concentration-dependent differences in laying order or absolute concentrations. Conflicting research exists both confirming (Custer et al. 1990; Pan et al. 2008; van den Steen et al. 2006) and rebutting 
(Reynolds et al. 2004) the idea that eggs from the same clutch have similar concentrations. First, middle, or ultimate eggs of two passerine species had nearly equal likelihood of containing the maximum concentration of DDE from a given clutch (Reynolds et al. 2004). Similarly, concentrations of $\Sigma \mathrm{PCDD} / \mathrm{DF}$ in eggs from house wrens, tree swallows, and eastern bluebirds from this study had within-clutch variability that would suggest that no relationship exists between residue concentrations and order in which eggs were laid. The results of this study are consistent with the conclusion made by Reynolds et al. (2004), that spatial distribution of contaminants on-site and daily feeding patterns likely affect concentrations of contaminants in eggs more than lay order.

In contrast with other primarily PCB contaminated study sites (Arenal et al. 2004; Custer et al. 2002, 2003, 2006; Neigh et al. 2006a, b; Secord et al. 1999), concentrations of PCBs on the Tittabawassee River were similar to the reference areas or at "background" for all species. Similarly, concentrations of $\Sigma$ DDXs in eggs of all three study species were again similar to other reference or non-point-source impacted sites across the United States (Custer et al. 2000, 2002, 2005; Harris and Elliott 2000; Neigh et al. 2006a, b).

\section{TCDD Equivalents (TEQ $\left.{ }_{\text {WHO-Avian }}\right)$}

The $\mathrm{TEQ}_{\mathrm{WHO}}$-Avian concentrations in eggs and nestlings of house wrens, tree swallows, and eastern bluebirds were greater at downstream SAs, and, like $\Sigma \mathrm{PCDD} / \mathrm{DF}$ concentrations, they were greatest at the T-6 location. One possible explanation for consistently greatest values at the T-6 location involves the natural hydrology of the Tittabawassee River. When at flood stage, the river flows across the large bends near T-6 instead of following the normal river channel (Fig. 1). The water loses momentum and energy quickly and deposits large amounts of sediment over those areas, creating a "sink" location for sedimentbound contaminants.

Based on site-specific contamination and a gradient of exposures among locations, correlations were expected between concentrations of $\Sigma \mathrm{PCDD} / \mathrm{DF}$ and TEQ ${ }_{\text {WHO-Avian. }}$. $\mathrm{TEQ}_{\mathrm{WHO}}$-Avian and $\Sigma \mathrm{PCDD} / \mathrm{DF}$ concentrations for eggs and nestlings were positively correlated for all study species (Fig. 5). This was due to the consistent prevalence of three congeners with high $\mathrm{TEF}_{\mathrm{WHO}-\mathrm{Avian}}$ values at SAs. Three PCDD/DF congeners (2,3,7,8-TCDF, 2,3,4,7,8-PeCDF, and 1,2,3,7,8-pentachlorodibenzo- $p$-dioxin) have $\mathrm{TEF}_{\mathrm{WHO}}$ Avian (van den Berg et al. 1998) values equivalent to TCDD. Combined with TCDD, these four congeners make up between 85 and $95 \%$ of the TEQ ${ }_{W H O-A v i a n}$ concentrations for both eggs and nestlings at the Tittabawassee River and Saginaw River SAs. Individual congener correlations for the concentrations of $17 \mathrm{PCDD} / \mathrm{DFs}$ and
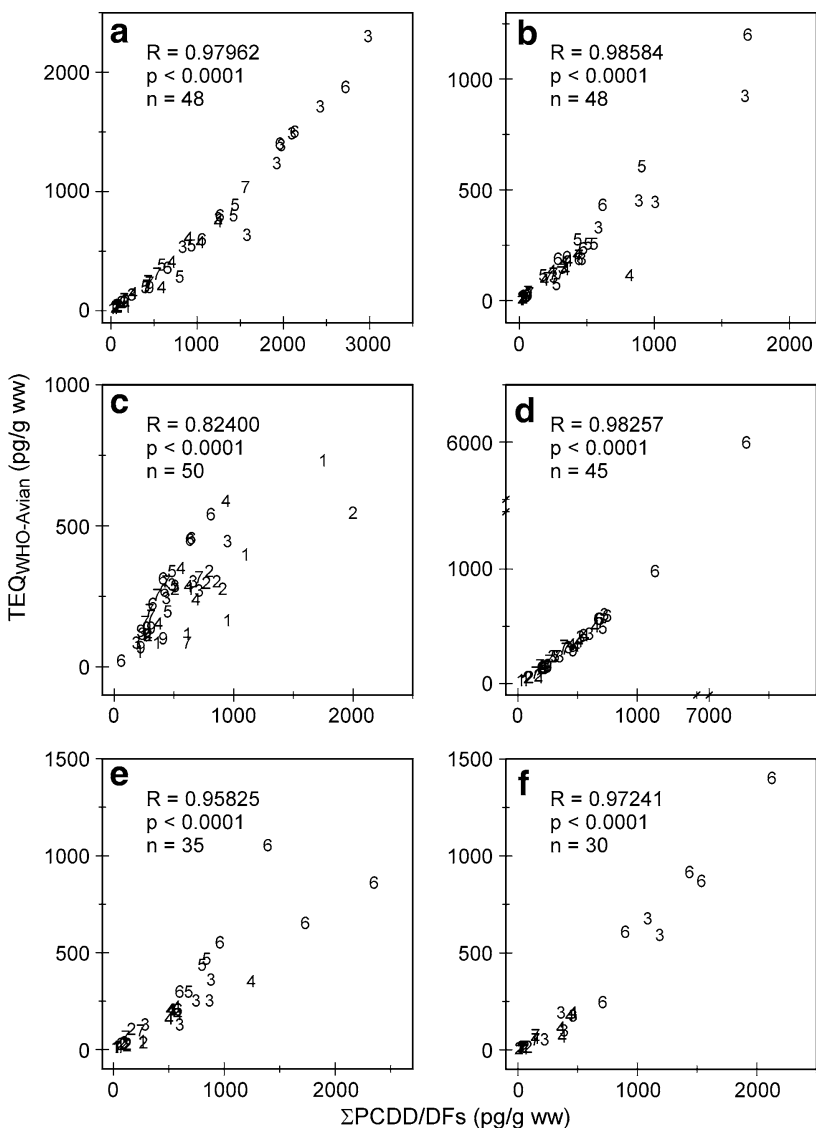

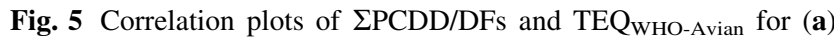
house wrens eggs, (b) house wren nestlings, (c) tree swallow eggs, (d) tree swallow nestlings (note: axis breaks), (e) eastern bluebird eggs, and (f) eastern bluebird nestlings collected in 2005-2007 near Midland, Michigan with indications of $R$ values, $p$-values and sample size. $1=\mathrm{R}-1 ; 2=\mathrm{R}-2 ; 3=\mathrm{T}-3 ; 4=\mathrm{T}-4 ; 5=\mathrm{T}-5 ; \quad 6=\mathrm{T}-6$; $7=\mathrm{S}-7 ; 9=\mathrm{S}-9$

TEQ $s_{\mathrm{WHO}-\mathrm{Avian}}$ for eggs and nestlings by species were all highly correlated (unpublished data). Strong positive correlations indicate a site-specific contaminant gradient among samples across study areas.

An egg collected from a house wren nest at T-4 contained the greatest measured concentration of $\Sigma \mathrm{PCDD} / \mathrm{DF}$ from this study $(7200 \mathrm{ng} / \mathrm{kg})$. The primary constituent was octachlorodibenzo- $p$-dioxin and the concentration of TEQ was only $350 \mathrm{ng} / \mathrm{kg}$ TEQ ${ }_{\text {wHO-Avian}}$, which was made up of congeners that represented only $5 \%$ of the $\Sigma \mathrm{PCDD} / \mathrm{DF}$ concentration. The egg was collected in mid-May 2005, was the third egg laid in the clutch, and the adult female was never recaptured again on-site. For comparison, at RAs, egg and nestling mean percent $\Sigma \mathrm{PCDD} / \mathrm{DF}$ of $\mathrm{TEQ}_{\mathrm{WHO}-\mathrm{Avian}}$ concentrations ranged from 23 to $33 \%$ and from 16.5 to $42.2 \%$, respectively, whereas at SAs, egg and nestling means ranged from 40 to $55 \%$ and from 39 to $73 \%$, respectively. Due to this discrepancy, this egg was removed from correlations between $\mathrm{TEQ}_{\mathrm{WHO}-\mathrm{Avian}}$ and 
$\Sigma \mathrm{PCDD} / \mathrm{DF}$ concentrations as an outlier (Fig. 5). The nestling tree swallow that had the greatest concentration of $\Sigma \mathrm{PCDD} / \mathrm{DF}$ also had the greatest concentration of $\mathrm{TEQ}_{\mathrm{WHO} \text {-Avian }}$ of $6000 \mathrm{ng} / \mathrm{kg}$. Unlike the egg sample from the house wren that was dropped from the correlation analyses, the congener pattern of this sample correlated well with the other tree swallow samples (Fig. 5).

\section{Congener Patterns}

Concentrations of $\Sigma \mathrm{PCDD} / \mathrm{DF}$ in tree swallow eggs were similar at RAs compared to SAs but not so for the other two species (Table 1). The congener profile for tree swallows, however, was dominated by dioxins at RAs, compared to furans at SAs (Fig. 4). As expected, concentrations of $\Sigma \mathrm{PCDD} / \mathrm{DF}$ and profiles of relative proportions of congeners in tree swallow nestlings had greater concentrations at SAs that were dominated by furan congeners. Moreover, PCA loading scores for the first and second components separated relative congener proportions of $\Sigma \mathrm{PCDD} / \mathrm{DF}$ concentrations by species and study location (Fig. 3). These details support the hypothesis that adult females, prior to breeding, are potentially exposed to primarily PCDDs at a proximal contaminated site near the RAs. Because foraging ranges are limited for adults feeding nestlings (Quinney and Ankney 1985), nestling dietary exposure at RAs would not include the proximal contaminated site. This explains why tree swallow nestlings have near-background $\Sigma$ PCDD/DF concentrations and a similar congener profile compared to other samples collected at RAs.

Previous research on concentrations of $\Sigma \mathrm{PCDD} / \mathrm{DF}$ on the Tittabawassee River has shown that soil and sediment congener profiles are dominated by PCDF congeners (Hilscherova et al. 2003). As expected, at downstream SAs, $\Sigma$ PCDD/DF congener profiles in passerine egg and nestling samples had a similar congener pattern to site-specific soils and sediments (Hilscherova et al. 2003) for all three species (Fig. 4). Interestingly, the reasons why tree swallow egg and nestling congener profiles at SAs contained greater percentages of 2,3,7,8-TCDF compared to tissues of terrestrial foraging house wrens and eastern bluebirds were probably associated with different dietary exposures. On the Woonasquatucket River, adult tree swallow females deposited greater concentrations of TCDD in eggs (Custer et al. 2005) compared to proximal sites with lesser TCDD concentrations. At that site, however, terrestrial foraging species were not studied, so differences in tissue accumulation for TCDD for terrestrial foraging passerines is largely unknown. However, it is possible that there are not only species-specific but also congener-specific accumulation, sequestration, metabolism, and deposition differences that could account for the differences (Kubota et al. 2006).

\section{Conclusions}

Overall, egg and nestling exposures for house wrens, tree swallows, and eastern bluebirds were greater downstream of Midland than upstream, and the downstream congener pattern was dominated by furan congeners, rather than PCDDs, which were dominant upstream. Eggs of tree swallows at RAs had $\Sigma$ PCDD/DF and TEQ ${ }_{W H O}$-Avian concentrations that were similar to SAs, albeit primarily based on PCDD congeners, compared to the PCDF congeners associated with eggs collected from SAs. Despite anomalies associated with tree swallow egg concentrations at RAs, nestling concentrations of both $\Sigma \mathrm{PCDD} / \mathrm{DF}$ and $\mathrm{TEQ}_{\mathrm{WHO}}$-Avian in all species studied were less at RAs compared to SAs. We stress the importance of site-specific tissue exposure monitoring and, due to the potentially different sources to each, the necessity of both egg and nestling samples. To our knowledge, this is the first site-specific study of passerines exposed to elevated concentrations of mixtures dominated by furan congeners. Cocontaminants, including DDXs and PCBs, were generally at background levels for all three species studied based on egg data, with the exception of $\Sigma$ PCB $\mathrm{TEQ}_{\mathrm{WHO} \text {-Avian }}$ in tree swallows. However, because only a small subset of tree swallow eggs was analyzed for PCBs, there is some uncertainty associated with this conclusion. Overall, based on egg and nestling tissue concentrations, passerine birds breeding in the Tittabawassee River floodplain downstream of Midland, Michigan have significant exposure to $\Sigma \mathrm{PCDD} / \mathrm{DFs}$. Subsequent articles will discuss implications of these results by incorporating data from dietary exposure (Fredricks et al. 2009a) and productivity (Fredricks et al. 2009c) into terrestrial-based (Fredricks et al. 2009b) and aquatic-based (Fredricks et al. 2009d) risk assessments of passerines nesting near Midland, Michigan.

\section{Animal Use}

All aspects of the study that involved the use of animals were conducted in the most humane way possible. To achieve that objective, all aspects of the study design were performed following standard operating procedures (Protocol for Monitoring and Collection of Box-Nesting Passerine Birds 03/04-045-00; Field studies in support of Tittabawassee River Ecological Risk Assessment 03/04-042-00) approved by Michigan State University's Institutional Animal Care and Use Committee (IACUC). All of the necessary state and federal approvals and permits (Michigan Department of Natural Resources Scientific Collection Permit SC1252, US Fish and Wildlife Migratory Bird Scientific Collection Permit MB102552-1, and subpermitted under US Department of the Interior Federal Banding Permit 22926) are on file at MSU-ATL. 
Acknowledgments The authors thank all the staff and students of the Michigan State University-Aquatic Toxicology Laboratory (MSU-ATL) field crew and researchers at ENTRIX Inc., Okemos, Michigan for their dedicated assistance. Additionally, we recognize Michael J. Kramer and Nozomi Ikeda for their assistance in the laboratory, James Dastyck and Steven Kahl of the US Fish and Wildlife Service Shiawassee National Wildlife Refuge for their assistance and access to the refuge property, the Saginaw County Park and Tittabawassee Township Park rangers for access to Tittabawassee Township Park and Freeland Festival Park, Tom Lenon and Dick Touvell of the Chippewa Nature Center for assistance and property access, and Michael Bishop of Alma College for his key contributions to our banding efforts as our Master Bander. We acknowledge the more than 50 cooperating landowners throughout the research area who granted us access to their property, making this research possible. Professor Giesy was supported by the Canada Research Chair program and an at-large Chair Professorship at the Department of Biology and Chemistry and Research Centre for Coastal Pollution and Conservation, City University of Hong Kong. Funding was provided through an unrestricted grant from The Dow Chemical Company, Midland, Michigan to J. P. Giesy and M. J. Zwiernik of Michigan State University.

Open Access This article is distributed under the terms of the Creative Commons Attribution Noncommercial License which permits any noncommercial use, distribution, and reproduction in any medium, provided the original author(s) and source are credited.

\section{References}

Adrian WJ, Stevens ML (1979) Wet versus dry weights for heavy metal toxicity determinations in duck liver. J Wildl Dis 15:125-126

Amendola GA, Barna DR (1986) Dow chemical wastewater characterization study: Tittabawassee River sediments and native fish. EPA-905/4-88-003. US Environmental Protection Agency, Westlake, $\mathrm{OH}$

Arenal CA, Halbrook RS, Woodruff M (2004) European starling (Sturnus vulgaris): avian model and monitor of polychlorinated biphenyl contamination at a Superfund site in southern Illinois, USA. Environ Toxicol Chem 23:93-104

Beal FEL (1915) Food of the robins and bluebirds of the United States. Bull US Dep Agric 171:1-31

Braune BM, Norstrom RJ (1989) Dynamics of organochlorine compounds in herring-gulls. 3. Tissue distribution and bioaccumulation in Lake-Ontario gulls. Environ Toxicol Chem 8:957-968

Burgess NM, Hunt KA, Bishop CA, Weseloh DV (1999) Cholinesterase inhibition in tree swallows (Tachycineta bicolor) and eastern bluebirds (Sialia sialis) exposed to organophosphorus insecticides in apple orchards in Ontario, Canada. Environ Sci Technol 18:708-716

Butler RW (1988) Population dynamics and migration routes of tree swallows, Tachycineta bicolor, in North America. J Field Ornithol 59:395-402

Custer TW, Pendleton G, Ohlendorf HM (1990) Within- and amongclutch variation of organochlorine residues in eggs of blackcrowned night-herons. Environ Monit Assess 15:83-89

Custer CM, Custer TW, Coffey M (2000) Organochlorine chemicals in tree swallows nesting in pool 15 of the upper Mississippi River. Bull Environ Contam Toxicol 64:341-346

Custer TW, Custer CM, Dickerson K, Allen K, Melancon MJ, Schmidt LJ (2001) Polycyclic aromatic hydrocarbons, aliphatic hydrocarbons, trace elements, and monooxygenase activity in birds nesting on the North Platte River, Casper, Wyoming, USA. Environ Toxicol Chem 20:624-631

Custer TW, Custer CM, Hines RK (2002) Dioxins and congenerspecific polychlorinated biphenyls in three avian species from the Wisconsin River, Wisconsin. Environ Pollut 119:323-332

Custer CM, Custer TW, Dummer PM, Munney KL (2003) Exposure and effects of chemical contaminants on tree swallows nesting along the Housatonic River, Berkshire county, Massachusetts, USA, 1998-2000. Environ Toxicol Chem 22:1605-1621

Custer CM, Custer TW, Rosiu CJ, Melancon MJ, Bickham JW, Matson CW (2005) Exposure and effects of 2,3,7,8-tetrachlorodibenzo- $p$-dioxin in tree swallows (Tachycineta bicolor) nesting along the Woonasquatucket River, Rhode Island, USA. Environ Toxicol Chem 24:93-109

Custer TW, Custer CM, Goatcher BL, Melancon MJ, Matson CW, Bickham JW (2006) Contaminant exposure of barn swallows nesting on Bayou D'Inde, Calcasieu Estuary, Louisiana, USA. Environ Monit Assess 121:543-560

Echols KR, Tillitt DE, Nichols JW, Secord AL, McCarty JP (2004) Accumulation of PCB congeners in nestling tree swallows (Tachycineta bicolor) on the Hudson River, New York. Environ Sci Technol 38:6240-6246

Elliott JE, Norstrom RJ, Lorenzen A, Hart LE, Philibert H, Kennedy SW, Stegeman JJ, Bellward GD, Cheng KM (1996) Biological effects of polychlorinated dibenzo- $p$-dioxins, dibenzofurans, and biphenyls in bald eagle (Haliaeetus leucocephalus) chicks. Environ Toxicol Chem 15:782-793

Fairbrother A (2003) Lines of evidence in wildlife risk assessments. Hum Ecol Risk Assess 9:1475-1491

Fredricks TB, Giesy JP, Coefield SJ, Seston RM, Haswell MM, Tazelaar DL, Shotwell MS, Bradley PW, Moore JN, Roark SA, Zwiernik MJ (2009a) Dietary exposure of three passerine species to PCDD/DFs from the Chippewa, Tittabawassee, and Saginaw River floodplains, Midland, Michigan, USA. Environ Monit Assess (accepted)

Fredricks TB, Giesy JP, Coefield SJ, Seston RM, Tazelaar DL, Roark SA, Kay DP, Newsted JL, Zwiernik MJ (2009b) Multiple lines of evidence risk assessment of terrestrial passerines exposed to PCDFs and PCDDs in the Tittabawassee River floodplain, Midland, Michigan, USA. Hum Ecol Risk Assess (accepted)

Fredricks TB, Zwiernik MJ, Seston RM, Coefield SJ, Stieler CN, Tazelaar DL, Kay DP, Newsted JL, Giesy JP (2009c) Reproductive success of house wrens, tree swallows, and eastern bluebirds exposed to elevated concentrations of PCDFs in a river system downstream of Midland, Michigan, USA. Environ Toxicol Chem (in review)

Fredricks TB, Zwiernik MJ, Seston RM, Coefield SJ, Tazelaar DL, Roark SA, Kay DP, Newsted JL, Giesy JP (2009d) Multiple lines of evidence risk assessment of tree swallows exposed to dioxinlike compounds associated with the Tittabawassee River near Midland, Michigan, USA. Environ Toxicol Chem (in review)

Froese KL, Verbrugge DA, Ankley GT, Niemi GJ, Larsen CP, Giesy JP (1998) Bioaccumulation of polychlorinated biphenyls from sediments to aquatic insects and tree swallow eggs and nestlings in Saginaw Bay, Michigan, USA. Environ Toxicol Chem 17: 484-492

Giesy JP, Ludwig JP, Tillitt DE (1994) Deformities in birds of the Great-Lakes region assigning causality. Environ Sci Technol 28: A128-A135

Guinan DM, Sealy SG (1987) Diet of house wrens (Troglodytes aedon) and the abundance of the invertebrate prey in the duneridge forest, Delta Marsh, Manitoba. Can J Zool 65:1587-1596

Harris ML, Elliott JE (2000) Reproductive success and chlorinated hydrocarbon contamination in tree swallows (Tachycineta bicolor) nesting along rivers receiving pulp and paper mill effluent discharges. Environ Pollut 110:307-320 
Head JA, Hahn ME, Kennedy SW (2008) Key amino acids in the aryl hydrocarbon receptor predict dioxin sensitivity in avian species. Environ Sci Technol 42:7535-7541

Heinz GH, Stebbins KR, Klimstra JD, Hoffman DJ (2009) A simplified method for correcting contaminant concentrations in eggs for moisture loss. Environ Toxicol Chem 28:1425-1428

Henny CJ, Blus LJ (1986) Radiotelemetry locates wintering grounds of DDE-contaminated black-crowned night-herons. Wildl Soc Bull 14:236-241

Henny CJ, Olson RA, Meeker DL (1977) Residues in common flicker and mountain bluebird eggs one year after a DDT application. Bull Environ Contam Toxicol 18:115-122

Hilscherova K, Kannan K, Nakata H, Hanari N, Yamashita N, Bradley PW, McCabe JM, Taylor AB, Giesy JP (2003) Polychlorinated dibenzo- $p$-dioxin and dibenzofuran concentration profiles in sediments and flood-plain soils of the Tittabawassee River, Michigan. Environ Sci Technol 37:468-474

Hoffman DJ, Melancon PN, Klein JD, Eisemann JD, Spann JW (1998) Comparative developmental toxicity of planar polychlorinated biphenyl congeners in chickens, American kestrels and common terns. Environ Toxicol Chem 17:747-757

Horn DJ, Benninger-Truax M, Ulaszewski DW (1996) The influence of habitat characteristics on nest box selection of eastern bluebirds (Sialia sialis) and four competitors. Ohio J Sci 96: $57-59$

Karchner SI, Franks DG, Kennedy SW, Hahn ME (2006) The molecular basis for differential dioxin sensitivity in birds: Role of the aryl hydrocarbon receptor. Proc Natl Acad Sci USA 103:6252-6257

Kubota A, Iwata H, Tanabe S, Yoneda K, Tobata S (2006) Congenerspecific toxicokinetics of polychlorinated dibenzo- $p$-dioxins, polychlorinated dibenzofurans, and coplanar polychlorinated biphenyls in black-eared kites (Milvus migrans): cytochrome P450A-dependent hepatic sequestration. Environ Toxicol Chem 25:1007-1016

Kuerzi RG (1941) Life history studies of the tree swallow. Proc Linn Soc NY 52-53:1-52

Langin KM, Norris DR, Kyser TK, Marra PP, Ratcliffe LM (2006) Capital versus income breeding in a migratory passerine bird: evidence from stable-carbon isotopes. Can J Zool 84:947-953

Larson JM, Karasov WH, Sileo L, Stromborg KL, Hanbidge BA, Giesy JP, Jones PD, Tillitt DE, Verbrugge DA (1996) Reproductive success, developmental anomalies, and environmental contaminants in double-crested cormorants (Phalacrocorax auritus). Environ Toxicol Chem 15:553-559

Mandal PK (2005) Dioxin: a review of its environmental effects and its aryl hydrocarbon receptor biology. J Comp Physiol B 175: 221-230

Mayne GJ, Martin PA, Bishop CA, Boermans HJ (2004) Stress and immune response of nestling tree swallows (Tachycineta bicolor) and eastern bluebirds (Sialia sialis) exposed to nonpersistent pesticides and $\mathrm{p}, \mathrm{p}^{\prime}$-dichlorodiphenyldichloroethylene in apple orchards of southern Ontario, Canada. Environ Toxicol Chem 23:2930-2940

McCarty JP (1997) Aquatic community characteristics influence the foraging patterns of tree swallows. Condor 99:210-213

McCarty JP, Secord AL (1999) Reproductive ecology of tree swallows (Tachycineta bicolor) with high levels of polychlorinated biphenyl contamination. Environ Toxicol Chem 18:14331439

McCarty JP, Winkler DW (1999) Foraging ecology and diet selectivity of tree swallows feeding nestlings. Condor 101: 246-254

Mengelkoch JM, Niemi GJ, Regal RR (2004) Diet of the nestling Tree Swallow. Condor 106:423-429

Nager RG (2006) The challenges of making eggs. Ardea 94:323-346
Neigh AM, Zwiernik MJ, Bradley PW, Kay DP, Jones PD, Holem RR, Blankenship AL, Strause KD, Newsted JL, Giesy JP (2006a) Accumulation of polychlorinated biphenyls from floodplain soils by passerine birds. Environ Toxicol Chem 25:1503-1511

Neigh AM, Zwiernik MJ, Bradley PW, Kay DP, Park CS, Jones PD, Newsted JL, Blankenship AL, Giesy JP (2006b) Tree swallow (Tachycineta bicolor) exposure to polychlorinated biphenyls at the Kalamazoo River Superfund Site, Michigan, USA. Environ Toxicol Chem 25:428-437

Neigh AM, Zwiernik MJ, Joldersma CA, Blankenship AL, Strause KD, Millsap SD, Newsted JL, Giesy JP (2007) Reproductive success of passerines exposed to polychlorinated biphenyls through the terrestrial food web of the Kalamazoo River. Ecotoxicol Environ Saf 66:107-118

Norstrom RJ, Risebrough RW, Cartwright DJ (1976) Elimination of chlorinated dibenzofurans associated with polychlorinated biphenyls fed to mallards (Anas platyrhynchos). Toxicol Appl Pharmacol 37:217-228

Nosek JA, Craven SR, Sullivan JR, Hurley SS, Peterson RE (1992a) Toxicity and reproductive effects of 2,3,7,8-tetrachlorodibenzop-dioxin in ring-necked pheasant hens. $\mathrm{J}$ Toxicol Environ Health 35:187-198

Nosek JA, Craven SR, Sullivan JR, Olson JR, Peterson RE (1992b) Metabolism and disposition of 2,3,7,8-tetrachlorodibenzo- $p$ dioxin in ring-necked pheasant hens, chicks, and eggs. J Toxicol Environ Health 35:153-164

Nosek JA, Sullivan JR, Craven SR, Gendron-Fitzpatrick A, Peterson RE (1993) Embryotoxicity of 2,3,7,8-tetrachlorodibenzo- $p$ dioxin in the ring-necked pheasant. Environ Toxicol Chem 12: $1215-1222$

Pan C, Zheng G, Zhang Y (2008) Concentrations of metals in liver, muscle and feathers of tree sparrow: age, inter-clutch variability, gender, and species differences. Bull Environ Contam Toxicol $81: 558-560$

Parren SG (1991) Evaluation of nest-box sites selected by eastern bluebirds, tree swallows, and house wrens. Wildl Soc Bull 19:270-277

Peakall DB, Gilman AP (1979) Limitations of expressing organochlorine levels in eggs on a lipid-weight basis. Bull Environ Contam Toxicol 23:287-290

Powell DC, Aulerich RJ, Meadows JC, Tillitt DE, Giesy JP, Stromborg KL, Bursian SJ (1996) Effects of 3,3',4,4',5-pentachlorobiphenyl (PCB 126) and 2,3,7,8-tetrachlorodibenzo-pdioxin (TCDD) injected into the yolks of chicken (Gallus domesticus) eggs prior to incubation. Arch Environ Contam Toxicol 31:404-409

Powell DC, Aulerich RJ, Meadows JC, Tillitt DE, Kelly ME, Stromborg KL, Melancon MJ, Fitzgerald SD, Bursian SJ (1998) Effects of 3,3',4,4',5-pentachlorobiphenyl and 2,3,7,8-tetrachlorodibenzo- $p$-dioxin injected into the yolks of double-crested cormorant (Phalacrocorax auritus) eggs prior to incubation. Environ Toxicol Chem 17:2035-2040

Prescott HW (1982) Using paired nesting boxes to reduce swallowbluebird competition. Sialia 4:3-7

Quinney TE, Ankney CD (1985) Prey size selection by tree swallows. Auk 102:245-250

Rappe C, Kjeller LO, Kulp SE, Dewit C, Hasselsten I, Palm O (1991) Levels, profile and pattern of PCDDs and PCDFs in samples related to the production and use of chlorine. Chemosphere 23:1629-1636

Reynolds KD, Skipper SL, Cobb GP, McMurry ST (2004) Relationship between DDE concentrations and laying sequence in eggs of two passerine species. Arch Environ Contam Toxicol 47:396401

Secord AL, McCarty JP, Echols KR, Meadows JC, Gale RW, Tillitt DE, McCarty JP, Echols KR, Meadows JC, Gale RW, 
Tillitt DE (1999) Polychlorinated biphenyls and 2,3,7,8-tetrachlorodibenzo- $p$-dioxin equivalents in tree swallows from the upper Hudson River, New York State, USA. Environ Toxicol Chem 18:2519-2525

Shaw GG (1983) Organochlorine pesticide and PCB residues in eggs and nestlings of tree swallows, Tachycineta bicolor, in Central Alberta. Can Field Nat 98:258-260

Stickel LF, Wiemeyer SN, Blus LJ (1973) Pesticide residue in eggs of wild birds: adjustment for loss of moisture and lipid. Bull Environ Contam Toxicol 9:193-196

Stutchbury BJ, Robertson RJ (1987) Do nest building and first egg dates reflect settlement-patterns of females. Condor 89:587-593

Svensson BG, Barregard L, Sallsten G, Nilsson A, Hansson M, Rappe C (1993) Exposure to polychlorinated dioxins (PCDD) and dibenzofurans (PCDF) from graphite-electrodes in a chloralkali plant. Chemosphere 27:259-262

Thiel, DA, Martin SG, Duncan JW, Lemke MJ, Lance WR, Peterson RE (1988) Evaluation of the effects of dioxin-contaminated sludges on wild birds. In: Proceedings 1988 technical association of pulp and paper environmental conference, Charleston, SC, USA, April 18-20, 1988, pp 145-148

US Environmental Protection Agency (USEPA) (1998) Polychlorinated dibenzodioxins (PCDDs) and polychlorinated dibenzofurnas (PCDFs) by high-resolution gas chromatography/highresolution mass spectrometry (HRGC/HRMS). Revision 1. Method 8290A. SW-846. US Environmental Protection Agency, Washington, DC

van den Berg M, Birnbaum L, Bosveld ATC, Brunstrom B, Cook P, Freeley M, Giesy JP, Hanberg A, Hasegawa R, Kennedy SW, Kubiak T, Larsen JC, van Leeuwen R, Liem AKD, Nolt C, Peterson RE, Poellinger L, Safe S, Schrank D, Tillitt D, Tysklind M, Younes M, Waern F, Zacharewski T (1998) Toxic equivalency factors (TEFs) for PCBs, PCDDs, PCDFs for humans and wildlife. Environ Health Perspect 106:775-792

van den Steen E, Dauwe T, Covaci A, Jaspers VLB, Pinxten R, Eens $M$ (2006) Within- and among-clutch variation of organohalogenated contaminants in eggs of great tits (Parus major). Environ Pollut 144:355-359 